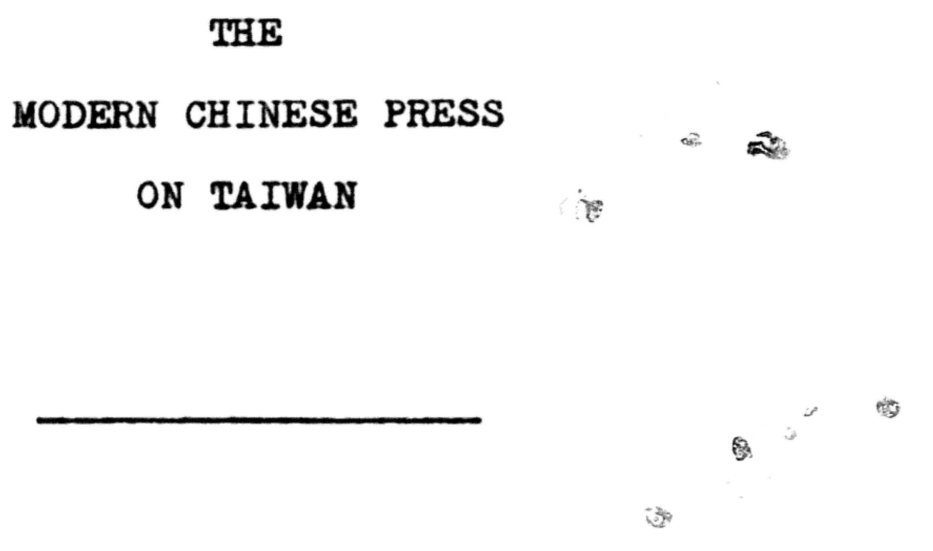

A Thesis

Presented to

the Faculty of the Graduate School

University of Missour?

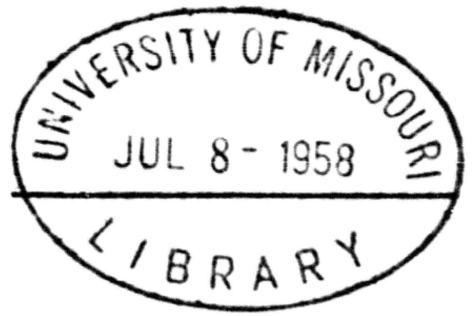

In Partial Fulfillment

of the Requirements for the Degree

Master of Arts

by

Hwa Shu Long

May, 1958 
The undersigned, appointed by the Dean of the Graduate Faculty, have examined a thesis entitled

2

\section{THE MODERN CHINESE PRESS ON TAIWAN}

presented by

\section{Hwa Shuis Long}

a candidate for the degree of

\section{Master of Arts}

and hereby certify that in their opinion it is worthy of acceptance.

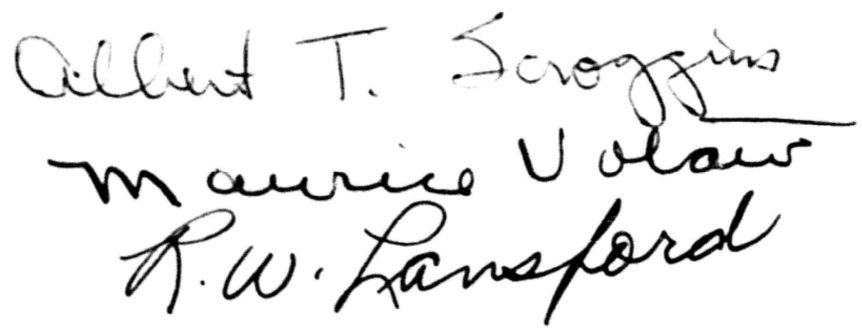




\section{ACKNOWLEDGMENTS}

The writer wishes to express sincere gratitude to his adeser, Professor Albert T. Scroggins, for his wise counsel, his enthusiastic guldance and patience, and his encouragement throughout the course of this study.

The writer is also grateful to Profesisor Maurice E. Votaw for his patient understanding and valuable suggestions in the research and preparation of this work. is 


\section{TABLE OF CONTENTS}

CHAPTER

I. INTRODUCTION • • • • • • • • • • • •

Statement of the Problem

Importance of the Study

Source of Data

Organization

II. ORgANIZATION OF THE CHINESE NEWSPAPER • •

Organizationel Chart of Chinese Newspapers

III. MAJOR MORNING DAILIES • • • • • • • • •

The Central Daily Ners

Taiwan Hsin Sheng Pao

Chung Hwa Da1ly News

The United Daily News

The Credit Information

Kung Lun Pao

IV. ENGLISH LANGUAGE DAILIES • • • • • • •

China News

China Post

V. EVENING NEWSPAPERS - • • • • • • • • •

Tah Hwa Evening News

Tze L1 Evening Post

Min Tsu Evening Ners 
CHA PTER

PAGE

VI. THE NEWS AGENCIES AND INFORMATION SERVICES -

The Central News Agency

The Pan-Asia Newspaper Allianco

Chjna News and Publication Service

Government Information Office

Office of Information, Ministry of National Defense

Information Department, Taiwan Provincial Government

The China Union Press

Cheng Hsin News Agency

VII. FREEDOM OF THE PRESS • . . . . . . . 108

VIII. ADVERTISING • • • • • • • • • • • • 127

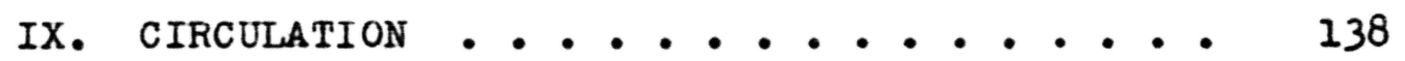

X. TRANSLATION OF FOREIGN NEWS IN THE CHINESE

PRESS ................. 148

BIBLIOGRAPHY •. • . . . . . . . . . . 164 


\section{CHAPTER I}

\section{INTRODUCTION}

Statement of the Problem

To understand the modern Chinese press on Taiwan, it is helpful to know something about the geographical surroundings and history of that island. Talwan, known as Formosa to Westerners, is a semi-tropical 1sland of 13,837 square miles, oblong in shape, lying off the Chine mainland and straddling midway the sea lanes between the Philippines and the Ryukyus.

The 1sland was ceded to Japan at the end of the first Sino-Japanese war in 1895, under the Treaty of Shimonosek1, and was returned to the Republic of China after the Second World War, in 1945, in accordance with the Cairo Declaration of 1943. When Chinese Communists seized the China mainland in 1949, the Chinese Central Government moved to Taiwan and has since made it the center of Free China's anti-Communist resistance and a bastion of democracy in the Far East.

When the Chinese Central Government took over the island in 1945, there was only one newspaper on the whole 1sland. It was the Taiwan Hsin PaO, a Japanese-language daily with a circulation of a little more than 100,000 agrinst a population of $6,000,000$.

The first and foremost problem confronting the early 
newspapermen coming to the island was the language difficulty, since Japanese was the only language allowed during the Japanese occupation. In fact, most of the islanders cou neither read Chinese nor speak mandarin when the 1sland was returned to China.

With the popularization of the Chinese language by the provincial government and with the Central Government retreating to the island following the Communist seizire of the mainland, newspapers began to boom on the island. In 1047 there were seventeon daliles. However, in the years following, only half of them survived. Today, according to the China Handbook 1956-57, there are altogether thirtytwo newspapers currently being published on Talwan. The total dally circulation of all the newspapers combined is Sestimated to be 336,706 and the population is approximately $10,000,000$

If an enlightened public is the best security of a nation, then that enlightenment is a task which newspapers must shoulder. Today, in the face of continual Communist threats in the Far East, the role of the Chinese newspapers is all the more important in enlightening the public to the dengers and prospects. While the Republic of China is endeavoring to adopt the democratic form of government, the position of the Chinese newspapers as a medium to reflect and shape public opinion deserves serlous re-evaluation. In view of these facts, a study of the modern Chinese press on Ta1wan probably is as justifiable as it is necessary. 
The purpose of this study is two-fold. One is to present facts about the present conditions of the Chinese press on Taiwan whereupon the Republic of Chine is based. The other is to evaluate the developments and limitations of the Chinese press as it tries to become a more effective and stronger means of mass communication on Talwan.

Importance of the Study

The study is limited principally to newspapers, both Chinese and English-language dellies, currently being published on Ta1wan. Magazines and other forms of publications are not included. To limit the scope and to select newspapers that are more representative of the modern Chinese press, only the leading dailies are sampled for study. Mention must be made that although there are thirty-two newspapers published in the Republic of China, nearly all the leading newspapers are centered in Taipei, chiefly because Taipel, being the capital, is the political, economic and cultural center of the nation. In addition, important news agencies and news services are covered to show how the newspapers are provided with the facilities of these growing agencies. Other phases of the modern Chinese press, such as freedom of press, conditions of advertising and circulation are also covered.

Source of Data

Much of the information for this thesis was gathered from publications concerning Chinese jounnaliam. These 
publications, ranging from newspapers and magazines to perlodicals, business reports and directorles, form the backbone of this study. Correspondence with editors and concernog persorthel of some of the newspapers and news agencies further contributes to the study with valuable first-hand information.

The sources of data in the form of publications used are these:

China Handbook, 1956-57-A reference book, mainly a record of wat the Central Government of the Republic of China accomplished in 1955. The book contains a section which deals exclusively with the present conditions of the Chinese press on Taiwan. Much of the information with regard to persons discussed in this study is taken from the chapter on who's who in China.

Pao Hsiu-Pao Hsiu, meaning journalism, is a periodical devoted to the study of journalism. It is the Chinese equivalent of the American Journalism Quarterly except that Pao Hsiu is published only twice a year. The periodical contains articles on nearly all phases of journalism, both Chinese and international.

Ten Years in Taiwan-This publication by the Talwan Hsin Sheng Pao contributes much of the information needed in covering the Hsin Sheng Pao and the development of Chinese journalism since 1945. "The Taiwan Press in the Past Ten Years" and "The Taiwan Hsin Sheng Pao in the Past Ten Years" are two articles that provide much valuable 
information.

Central Da1ly News special edition, March 12, 1957The special edition issued in honor of both the twentyelghth anniversary of the Central Daily Nows and also its elghth year of publication on Taiwan has a special section which is devoted to the development of the Chinese press over the past years. In fact, much of the information concerning the history and development of the various newspapers is based on articles in this section.

Business Correspondence of the Central News AgencyCoverage of the Central News Agency, the largest news gathering agency in the Republic of China, is based on the 30 th enniversary edition of the business correspondence.

Journalism Quarterly- Much of the information in the chapter on freedom of the press is taken from an article entitled "How Free Is the Press in Free China," in the fall, 1956, issue of the Journalism Quarterly.

East and West- This English-language monthly pubIlshed by the Sino-American Cultural and Economic Association, was used for quotations relative to freedom of the press.

Directory of Talwan 1958- This publication is valuable in that it gives general information about the history and development of the various aspects of the island. A list with the names of all the publishers and directors of the newspapers and news agencies is included. 
Mention must also be made that much valuable information about the various aspects of the Chinese press is made available through personal interviews with editors, reporters and responfible personnel of some of the Chineso newspapers, who are currently doing research in journalism at the University of Missour1.

Organization of the Study

The study is divided into eleven chapters. Chapter II deals with the organization in general of the Chinese press. A chart showing the organizational system of the Central Daily News, the most influential newspaper on Taiwan is provided. Chapter III is given over to the major morning newspapers, namely: the Central Daily News, Hsin Sheng Pao, China Daily News, United Da1ly News, Credit Information and Kung Lun Pao. Chapter IV covers the two English-language dailis, the China Post and Chine News; the latter is a mimeographed paper. The evening newspapers, Tah Hwa Evening News, Tzu L1 Evening Post and Min Tsu Evening News are covered in Chapter V. Chapter VI which deals with the Chinese news agencies and information services includes the Central News Agency, Pan-Asia Newspaper Alliance, China News and Publication Service, Ltd., Government Information Office, the Office of Information, Ministry of National Defense, the Information Department of the Taiwan Provincial Government and others. Freedom of the press is discussed in Chapter VII. Adver- 
tising and circulation are preserted respectively in Chapters VIII and IX. In view of the fact that translation of foreign news is an indispensable operation in the Chinese press in order to make international news digestIble to Chinese readers, Chapter $X$ is devoted to that effect. The final chapter is a conclusion which both sumarizes that which has been discussed and also attempts to point the direction toward which the modern Chinese press should strive. 


\section{CHAPTER II \\ ORGANIZATION OF THE CHINESE NEWSPAPER}

The most common form of newspaper ownersh1p on Talwan is the corporation. ${ }^{1}$ Th1s $1 \mathrm{~s}$ true on all the 1mportant newspapers, both private and publ1c-owned. The chlef reason for this is that the corporation is the type of organization that can accumulate a large amount of funds from investors. As most of the modern Chinese da111es are large-scale businesses, they require adequate cap1tal to operate. ${ }^{2}$ Another reason 1 s that the newspaper, 11ke other enterprises, 1s a business in 1tself. As a business, $1 \mathrm{t}$ naturally looks forward to expansion.

\section{THE ORGANIZATIONAL SYSTEM}

Although the objectives of the modern Chinese newspapers are as varied as they are different in titles, they generally follow the same organizational system. Under this system, control is maintalned in graduated levels with each stratum having 1ts final author1ty. The departments are headed by executives who are directly responsible to a

\footnotetext{
1P. Y. Hao, Newspaper Management In China (manuscript).

2 Ib1d.
} 
superior executive, but each is given full responsibility and authority within his own department. The system constitutes the following:

A. Stockholders' Conference--According to the

Chinese laws for corporation organization, the stockholders conference is the highest authority in a corporation. On privately owned newspapers the stockholders are the paper's investors; on party-owned newspapers the stockholders are representatives from the party. On the Central Da1ly News, for example, a newspaper operated by the Kuomintang, the highest authority on the paper is the conference representing the stockholders from the Kuomintang. 3 These stockholders actually do not own the stocks themselves; instead, they represent the interests and rights of the party. Stock of the Central Daily News is not for sale in the stock market. However, in the case of the Chung Hwa Daily News (China Daily News), also a Kuomintang-operated newspaper, 1ts stocks are purchasable. The Chung Hwa Daily News has a total of 2,100 shares of stock, of which 500 belong to outside investors. 4 At the stockholders' conference each share of stock has one vote. Thus, the more shares an investor has, the more powerful he becomes at the

3P. Y. Hao, Nowspaper Management in China (manuscript)

4Interview with P. Y. Hoo, former director of south edition of China Daily News, November 18, 1957. 
conference.

B. Board of D1rectors--Although the stockholders are owners or representatives of the newspaper, it is impossible for all of the stockholders to run the newspaper. Thus, a number of persons have to be selected from the stockholders to form a board of directors to act on behalf of the stockholders for their rights and interests. 5 In the case of party-owned newspapers, the stoekholders represent the rights and interests of the party.

The president of the board of directors is elected from this board. The board of directors appoints the general manager of the newspaper as well as determines the paper's overall policies. In addition, it is also responsible for electing several members from among the stockholders to set up a supervisory committee to ensure proper operation of the paper with partiqular interest in the paper's financial matters.

C. The General Manager--The general manager is appointed by the board of directors. He is the chief executive of the newspaper, and is responsible for matters such as personnel administration, budget estimating and, most important of ell, for implementing the policies laid down by the board of directors. On most of the newspapers,

5P. Y. Hao, Newspaper Management in China (manuscript). 
the general manager is from among the members of the board of directors, whereas on papers like the Central Da1ly News, the general manager usually is appointed by the party. The general manager in his capacity as the chief administrator of the paper is authorized by the board of directors to appoint qualified persons to the various departments. On some of the other papers, such appointments ave to be approved by the board of directors. 6 Assisting the general manager is an assistant manager who is also appoinfod by the board of directors.

D. The Publisher-According to the publishing law of China, every newspaper has to have a publisher to handle all legal matters involving the paper. On papers like Hsin Sheng Pao and the China Da1ly News, the publishers are the presidents of the board of directors. In the cage of the Central Daily News, the generel manager is the paper's publisher. However, on the United Daily News, the publisher is elected from the board of directors.?

\section{DEPARTMENTAL FUNCTIONS}

There are usually two departments under the direction of the general manager, the editing department and the (manuscript).

6P. Y. Hao, Newspaper Management in China

7 Ib1d. 
management department. Apart from these two departments, there are four other establishments: the editorial room, the secretariat, the accounting room and personnel administration. 8

The editing department is responsible for gathering news. Included in its functions are culling news, editing copy, writing headilnes, selecting features, cartoons and photographs. Editing, news, morgue and translation are the usual divisions under this department. In addition, it supervises the paper's stringers and forelgn correspondents

The management department directs advertising, circulation, mechanical work, administrative affalrs, job printing and maintains branch offices in areas where the paper 18 circulated. The functions of the branch offices include soliciting circulation, selling advertising space and gathering local news. These offices are set up in cities adjacent to where the paper 18 operated. Executives of the branch offices are not on the payroll of the paper, but are paid commissions on the basis of their soliciting efforts.

The editorial room directs the editorial page and oversees all matters pertaining to the newspaper's pollc1es. The chief of the room is elther a well-known writer or a man of high scholastic standing. As editorials are

8P. Y. Hao, Newspaper Management in China (manuscript). 
still enthusiastically read by the Chinese newspaper readers, this room usually enjoys a supreme position on the newspaper. There are three or four editorial writers besides the chief editoriel writer on most of the major morning newspapers. Each of these editorial writers is a specialist in one particular field. For example, the Central Daily News has five editorial writers specializing in such areas as the milltary, foreign affairs, politics, commerce and economics or other fields. This specialization enables each editorial to be expertly handled. When an occasion arises regarding newspaper policy on a certain problem, frequently a meeting of all concerned is called so that a final decision can be reached. 9

The chief function of the secretariat is to handle all secretarial work for the general manager, which includes keoping flles, drafting documents and making recommendations to the general manager on administrative affairs. Heading the secretariat is a chief secretary whose authority sometimes is only second to the general maneger or the assistant general manager.

The accounting room is an independent establishment. Organizationally, it is under the general manager; however, it takes orders directly from both the board of directors as well as the supervisory committee.

9Interview with P. Y. Hao, October 25, 1957. 
The auditors and accountants are controllers of the nowspaper's financial matters. Their main duties include: (1) general accounting, (2) departmental record-keeping, (3) cost finding and (4) budget estimating. All the key officers of this division are often appointed jointly by the board of directors and the supervisory committee. In some cases, they are appointed by the supervisory committee solely. 10

Another independent establishment is the personnel administration which is in charge of promotion, job evaluation, transfer, merit-rating, retirement, pension and welfare for the newspaper's employees. Like the accounting room, the personnel administration is under the control of the general manager and the board of directors as well as the supervisory committee. The purpose of this multicontrol is to prevent the general manager from using too many of his own associates, and to develop a sound personnel system within the newspaper.

The manfestation of the newspaper organization depends on how properly the organization 1s manned. Definite division of responsibility, competent personnel administration and full co-operation among the departments are essential to a successful operation on a newspaper. Lack$\therefore$ fing them, even the best type of newspaper organization is

10P. Y. HaO, Newspaper Organization in China (manuscript). 
vo1d. 11

III. PROBLEMS IN CHINESE NEWSPAPER ORGANIZATION

With authority being assigned by ranks or titles in a delegation of h1gher and lower positions, the Chinese newspaper is organized in the form of a pyramid. The most obvious problem in this pyramidic type of organization is that 1t places more control within the newspaper than it renders freedom of operation among the departments and varfous ot divisions. However, there are other problems :

A. Nearly all the major newspapers on Talwan are morning papers. As such the editing department does not work at the same time as the management department; the former works at night and the latter in the daytime. The different working schedule frequently prevents full coordination between these two departments. Besides, these two departments are parallel in the organizational channel. The flow of work 1s often jeopardized because each of the two departments has 1 ts own objectives which sometimes conflict with the other. For instance, when the business department wants to increase advertising in the paper, the editors may justiflably ins1st that news should occupy more

11P. Y. Hao, Nerspaper Organization in China (manuscript). 
space.12

B. Although the editing department works at night, the editorial writers are on the day shift. Thus, an editorial often show a lack of co-ordination with the news because of new developments after the oditorial has been completed. 13

C. Under the circumstances where the newspaper's finance is controlled by an independent establishment, freodom of operation by the management department is hindered. The department canrot aggressively launch any project that is not on the approved budget.

D. The mechenical set-up on the Chinese nerspaper is not a full department as on many large American nowspapers. It 1s only a division under the direction of the business department even on the largest Chinese newspaper. However, from the standpoint of operational convenience, it should be elther under the editing department or be elevated to a full department as on many of the American nowspapers.

E. The secretariat with the chief secretary in charge actually becomes the general manageis's chief of staff. He 1s empowered to decide administrative matters and is only second to the general manager in authority.

12 Interview with P. Y. Hao, October 25, 1957. 13 Interview with P. Y. Hao, October 25, 1957. 
Co-operation among the departments may likely be hindered if the chief secretary 18 incompetent or holds too much power in his hands.

F. The type of newspaper organization now popular In the modern Chinese press normally requires a large number of people. However, typesetters comprise a large percentage of the employees. For example, on the China Daily News (southern odition) fifty of 211 eployees (excluding carriers ans stringers) are typesetters. 14 Th1s 18 due to the fact that Chinese words are composed not of alphabets, but of characters. In fact, each word 18 represented by a character and there are as many as 9,000 characters in common use. The complicated Chinese language makes the IInotype machine Impractical in China. At present, all typesetting is done by hand; this requires many typesetters and much space in the composing room, particularly for type storage. Th1s system is expensive in both time and money. According to Y.P. Hao, former director of the southern edition, China Da1ly Ners, the most efficiont typesetter can set only about twenty-two words a minute. The development of a linotype machine suitable for the Chinese language has long been a coveted 1dea, for not only would it materially minimize the great number of personnel required, but it would also speed up operations.

\section{Ib1d.}


As nearly all the Chinese newspapers are organized in the form of a corporation, the following organizational chart of the Central Daily News, one of the largest newspapers on Ta1wan, is c1ted here as an example:

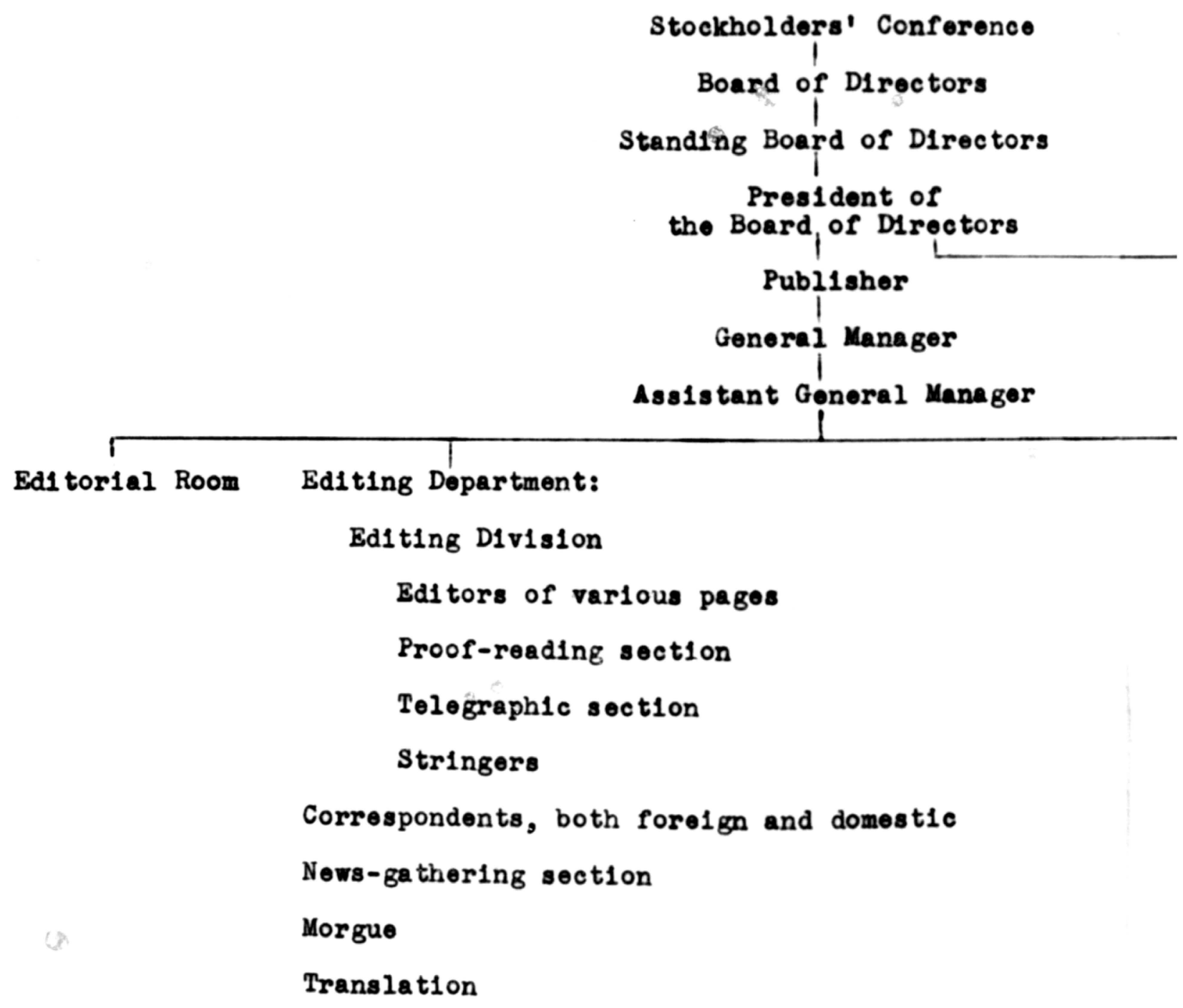


Supervisory Committee

Standing Supervisors

Auditors

Management Department

Secretariat
Accounting Personnel
Room
Administration

General Affaira Diviaton:

General affairs section

Material section

Cashier's section

Business Division:

Circulation section

Advertising section

Branch offices

Mechanical Division

Typesetting room

Pressroom

Stereotype room

Photoengraving room

Job Printing Division 
CHAPTER III

MAJOR MORNING DAILIES

The Central Da1ly News

The Central Da1ly News, known as Chung Yang J1h

Pao to the Chinese, is the official spokesman of the

Kuomintang, the Chinese Nationalist Party, of which

President Chlang Ka1-shek is the leader. The Daily Ners

has been the largest and the only continuously published

newspaper for the past twenty-nine years in the Republic

of Chlna, now on Talwan.

It was founded originally in Canton in 1926 by the

Revolutionary Party, forerunner of the Kuomintang, at a time when the integrity of China was threatened by the Chinese warlords who had occupled vast territories for personal gains without supporting the central government. ${ }^{1}$

The paper in 1 ts early stage was established with the responsibility to campalm for a united China. After the sweoping victory of the Revolutionary Army, the Daily News was moved in 1929 to Nanking where it made 1ts first appearance on February 1 the same year, thenceforth assuming 1 ts career as the leading and authoritative news-

l Paul H. C. Wang, "A Historical Study of the Chinese Press of 3,000 Yoars" (unpubl1shed Master's thesis, The University of Missour1, Columb1a, 1955), p. 88. 
paper in China. ${ }^{2}$ Later, the Daily Nows was developed into a gigantic chain of nowspapers throughout the nation with all the chain papers carrying the same name plate, Chung Yang J1h Pao, although published under separate managements.

In 1937 the Nanking Central Daily News moved to Chungking, the wartime capital of China, in the wake of the government to take up 1 ts new role in enlightening the public against Japanese domination. ${ }^{3}$ Acute material shortages (particularly in newsprint), constant threat of air raids, and frequent interruptions of power and water supply caused by enemy bomblings were among the hazards confronted by all the newspapers in wartime Chungking. The Central Da1ly News, despite 1 ts support from the party and 1 ts being a leading newspaper, was exposed to these same difficulties. The Daily News during the war printed 1ts paper in a dark, narrow and damp air raid tunnel, using ten flat bed presses so that the paper could come off the press faster and be ready for delivery on time. 4

The Japanese bombings of Chungking on May 3-4, 1939,

2Central Daily News, March 12, 1957 (28th Anniversary special edition).

3 Ib1d., March 1, 1956.

4rbid., March 12, 1957. 
turning the major part of the city into flames and ashes, paralyzed nearly all the city's newspapers. To evaluate the situation, the directors of the Chungking newspapers met the next day. posult was that a "United Ed1tion" would be put out jointly by all the newspapers. Nine dailies, all morning newspapers, jolned this united front. They were: the Central Da1ly News, Ta Kung Pao, Shih Tze Hsin Pao, Tsao Tang Pao, Hsin Chu Pao, Hsin Ming Pao, S1 Nan Jih Pao, Shan Wu J1h Pao, Kuo Ming J1h Pao and later the Communist party organ, Hsin Hwa Jih Pao also jolned the ranks. $5^{\circ}$ Tsang-Po Cheng, then director of the Central Daily News, was elected to head the joint committee for the "United Edition." The first issue of the "United Edition" came out on May 7, the day following the jolnt meeting of the directors. The joint efforts of the newspapers to keep the people informed of the news under adverse conditions, the abandoning of individual newspaper's policles, and the responsible attitude of the newspapermen working under enemy bombing and on meager salaries were among the factors that constituted the so-called "Chungking spirit."6 However, when member newspapers completed their evacuation plants in the suburbs of the c1ty, the "United Edition" was suspended on August 12, 1939 after a period of ninety-

\section{Ib1d. \\ 6Ib1d.}


nine days of joint operation. Thereafter, the ten partners resumed their individual publications. The years in Chungking were adverse for newspaper publishing, but the Chinese press was never discouraged. To meet the newsprint shortage, for instance, a native-made paper, dark, harsh and inferior in texture, was developed to substitute for the regular, imported newsprint. 7

When the government mosed back to Nanking after V-J Day in 1945, the Central Daily News resumed its publ1cation in Nanking after elght years' absence. Unfortunately, four years later the Communist rebellion on the China mainiand forced the Daily News into another exodus, this time to Taiwan. The first issue of the Taiwen Central Dg117 News came off the press on March 1, 1949, assuming 1ts role once again as the offlcial organ of the ruling party, the uomintang.

The advent of the Central Daily News gave great Impetus to the Taiwan press. First of all, the Daily News, being an authoritative newspaper representing the party and the government, caused all other newspapers in Talpel to change from local newspapers to newspapers characteristic of national interests. Secondly, the supreme performance of the Daily News' printing equipment stirred a competition among all the other newspapers for better printing facill-

\section{Ib1d.}


ties and for typographical improvement. Thirdly, the use of color in advertisements, attracting many advertisers to the Daily Ners, resulted in a vogue of using color in advertisements in other nerspapers. Fourthly, the Daily News pioneered in the use of comic serials; and lately, the addition of special pages and Sunday magazines to its contents has also influenced other newspapers. 8

Of the Daily Ners' twenty-nine jears of publication, Hsin-Yeh Ma, a graduate of the School of Journalism of the University of Misspurl (A.M., 145) was for seven years the director. At first, the paper, being an offlcial organ, was subsidized by the Kuomintang. However, after Ma took the post of publisher, the paper became a success both financially and journalistically. The year 1948 marked a great improvement in the paper. A Goss high-speed rotary press was bought in the United States and Installed. The new press, the first of Its kind ever used in Asia, is capable of printing 120,000 coples per hour. With the new press, the paper improved remarkably in typography. 9

When the paper resumed its publication in Taipei, it had only one piece of property that it could call its own-the Goss printing press it had moved out from the mainland. The paper then did not even have enough funds to pay 1 ts

\section{Ib1d. \\ 9 Ibid.}


employees' salaries. Despite all the difficulties confronting the paper, the first issue came out on March 12 , 1949.10

Unfortunately, a fire on November 11, 1949, swept from a nelghboring bullding, a restaurant, and burned down the entire establishment of the Daily News. But the paper continued to publish in the midst of devastation. The scene of its newspapermen working in the rain under umbrellas in the days after the fire was so miserable that it would long be remembered by 1 ts readers. Fire is destructive, but there is a Chinese superstition that fire, though destructive, will eventually bring prosperity to the vict1m. The paper did become prosperous later. But apparently, the oid superstition could not work any miracle. It was the untiring efforts of the paper's workers that made the Da1ly News presper. The destroyed building was soon rebuilt. New projects were added to the paper with the completion of the new building. A special plane was chartered to deliver papers to the other parts of the 1sland. Overseas editions for Hongkong and New York were started. Comics, draw by the Liang brothers, two famous artists, were added to lighten the contents of the Daily News. At that time Ma used to say to his colleagues that if the circulation could reach 2,000, then the Daily News 
could survive. Three years later the paper not only owned a spacious bullding with an efficient printing plant, but it had also bullt more than a hundred residences for 1 ts employees. In addition, circulation had increased to 50,000 and advertising revenue was at a new high. 11

The Central Daily News is noted for its competency in nows coverage and 1 ts authoritativeness in editorial eloquence. As a dally which represents the Kuominteng, the Central Daily News expresses the views of the government and the party. 12 The editorial stand of the Central Daily News can be summarized as follows:

(1) Advocating democracy, freedom, humant ty, peace and world brotherhood and ant1-Communism.

(2) Encouraging the endeavors in all fields for the recovery of the Chins. Mainland and offering suggestions and advice toward that direction.

(3) Serving as a bridge between the people and the government.

Because of newsprint shortage and financial limitations, all the Chinese language dallies on Taivan are sixpaged. However, on special occasions such as National Anniversary Day and New Year's Day, the newspapers traditionally issue "extras."

${ }^{11}$ Ib1d.

${ }^{12}$ Ch1na Handbook, $1954-55$, p. 189. 
Normally, the first page of the Daily News contains important news of the day, both national and international, with the bottom of the page reserved for advertisements. The second page carries the editorials and 18 also given over to national and international news of secondary importance. The third page is local news, weather reports, financial news, and market reports. Page four contains photogrephs and a supplementary section which is noted for its light amusing essays, short stories, pooms, travel sketches and book and movie reviews. Page five is community news while the last page is predominantly advertising. The Central Daily News weokly issues a women's page, a children's page and a map page. The women's page is devoted to subjects such as: love and marriage, family IIfe, housekeopling, famliy health and medical care, cooking and sewing, child psychology and education. The children's page has two major parts in its contents. The first part contains stories, comics and sketches. The second part 1s the school children's contributions which include stories, drawings and compositions.

The weekly map page is aimed at helping the readers to understand the current world issues with reference to their geographical backgrounds. Each $18 s u$ is concentrated on one particular territory where a big issue is at stake. The page usually contains maps, descriptions of the geographical situation and an analysis of the political, 
economic and military conditions there.

The Daily News has contributed in promoting public

welfare in the past few years. In 1955, for instance, it founded the readers' scholarships which were open to the public on a competitive basis. The total amount of scholarships in that year was NT $\$ 30,000$ (approximately $\$ 1,000$ U. S.) A committee composed of distingulshed educators and scholars was set up to decide scholarship winners. 13 The Daily Ners also extended 1ts concern to the victims of a flosd on the China mainland in 1954. A chest for raising relief funds was sponsored and NT $\$ 80,000$ in cash was collected plus food and clothes. With the money the paper bought tons of rice and had it alr-dropped to the flood victims trapped behind the Bamboo Curtain. 14 When the Taipien, a battleship, was sunk by the Communists in the fall of 1954, the Dafly News launched another campaign for ralsing funds to buy another battleship. This time the funds rocketed to NT\$12,000,000. The Chinese Navy, on the occasion of the paper's 10,000th issue, presented a model ship to the paper. The ship was christened "Readers of the Central Daily News." 15

Although the Daily News is a party-owned newspaper,

13Central Da1ly News, March 12, 1957.

14 Ibid.

15 Ib1d. 
It is an authoritative newspaper on Talwan, widely circulated and respected. It is the only paper on Taiwan that now has an international edition which is air-mailed daily to Chinese readers overseas. It 18 an authoritative newspaper in the Republic of China, and 1ts triumph owes a great deal to the efficient management of its varlous publishers, 1 ts authentic and wide coverage of news, its devotion to public service, its well-written and authoritative oditorials, 1ts handsome typography, 1 ts $\mathrm{rich}$ and varied contents. Today, the Central Daily News has cooperated effectively with the government in defiance of Communism. It stands firmly by the government and the Kuomintang and flghts determinedly for national independence, for human liberty and for democracy. As Free China's leading nowspaper, the present-day Central Dally News represents the will and spirit of both Chinese journalism and the Republic of China in volcing the ideals of a free world.

The Taiwan Hsin Sheng Pao

The Taiwan Hsin Sheng Pao (meaning New Life Journal) is an official organ of the Taiwan Provincial Government. It was the first newspaper published on Taiwan after the 1sland was returned to the Republic of China. 16 The first

\section{Ib1d.}


edition of the paper came out October 25, 1945, when the Chinese Government formally accepted the surrender of the Japanese mil1tary goverinment on Ta1wan. October 25, 1945 , was a big day in recent Chinese history, for it marked the return of the Province of Talwan to the Republic of China after fifty jears of occupation by the Japanese. To the 1slanders of Talwan, this date meant even more. It meant the beginning of a new life for them. It also signified that Chinese culture was to be reborn on Talwan, for under Japanese rule, the use of the Chinese language was prohib1ted. It was on account of these facts that the paper was named the Taiwan Hsin Sheng Pao. 17

Hsin Sheng Pao, as 1 t 18 thus called, took over the fac1lities of the Taiwan Hsin Pao at 1 ts ostabliabmont. The Taiwan Hsin Pao was a reault of the ooneolidation of s1x Japanese newspapers in 1944. The conool1dation was ordered by the Japanese milltary at a time when they wanted to economize on the 1sland's materials and to control more fully the press on Ta1wan. Thus, there is no connection between the old Taiwan Hsin Pao and the existing Taiwan Hoin Sheng Pao except that the latter took over the former's facilities. Hsin Sheng Pao is an entirely new paper. 18

17 Jan-Tze Shieh, Ten Years on Ta1wan, 1954, p. 280. 18 Ib1d. 
The first issue of the paper had four pages with advertisements on the front page, news on the second and third pages, news in Japanese on the fourth page and advertisements at the bottom. Highlight of the news in the first 1ssue was the arrival of the Governor of Talwan from the China mainland. The news was given generous space and printed against a black background in reverse printing. To enunciate Its mission to the readers, the Hsin Sheng Peo, in an editorial printed in the first issue, said:

Editorially and reportorially, the Hsin Sheng Pao is a Chinese newspaper in the sense that $1 t$ will speak for China. It will from now on use the stendard Chinese language to continuously introduce Chinese cultures, to cover elaborately the national news, to convey and explain government orders and regulationg and to reflect the opinions of the

In 1 ts early 1ssues the Hsin Sheng Pao reserved one fourth of its space for printing news in the Japanese language. 21 This was because of Taiwan's 50 years of Japanese occupation, during wich time the Chinese language was prohibited. Besides, most of the 1slanders, especially the younger generation, could not read Chinese, though they were able to speak the native dialect, which is similar to that used in the southern part of Fukien Province. 19Hsin Sheng Pao Business Report, October 25, 1956,

20 Central Da11y News, March 12, 1957.

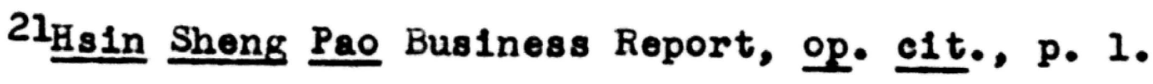


The Japanese-language section was abandoned one year after the paper's birth. 22 This was made possible through the continued efforts by the provincial government and various educational circles to popularize mandarin Chinese, the standard or official Chinese dialect. However, much credit must be given to the enthusiasm of the 1slanders in learning the standard dialect.

The flrst director of the Hsin Sheng Pao was Wan-Ch1 Lee, a journalist educated in France, who took over the Taiwan Hsin Pao at the ond of Sepember, 1945. In 1947, the paper was organized into a corporation with Lee as director of the paper. The Hsin Sheng Pao Corporation, Ltd., however, was formally organized in May, 1949.23 JanTze Shieh, a graduate of the School of Journalism of the University of Missouri (A.M., 145) was named director. To expand 1ts business, the Hsin Sheng Pao established a southern edition at Kaohsiung on June 20, 1949, to serve the readers in the southern part of the 1sland. 24

When the Hsin Sheng Pao first took over the facilities of the Taiwan Hsin Pao, the whole mechanical department was in bad shape because during the Second World War,

22 Jan-Tze Shieh, Ten Years on Taiman, p. 280. 23 Ib1d., p. 282.

24 Central Da117 News, March 12, 1957. 
the plant was badly bombarded. It was estimated that at least five 1,000-pound bombs had hit the plant, which left the place desolate and devasted. 25 It was under these adverse circumstances that the printing plant was taken over by the present Hsin Sheng Pao. However, when Jan-Tze Shieh became the director of the paper in 1949, new equipment was bought. Meanwhilo, old facilities were repaired and replenished with new parts. Among the equipment taken over from the Taiwan Hsin Pao was a printing machine called R. H. rotary press. It was made by a Japanese manufacturer who bought the blue-print of the machine from America. The machine, capable of printing 72,000 coples per hour, had been put in active service in 1954.26

The year 1954 was an 1mportant milestone in the development of the Hsin Sheng Pao. New equipment bought at the expense of approximately $\$ 129,000$ (U. S.) was installed in a new building wose construction cost the paper $\$ 78,000$ (U. S.). The most important equipment purchased was a printing press designed and made in Japan especially for the Hsin Sheng Pao. It was christened "The Hsin Sheng Pao N. F. A. super-speed multi-color rotary press." The new press is capable of printing 120,000

25 Hsin Sheng Pao Business Report, October 31, 1952. 26Ib1d., November 31, 1952. 
coples per hour, and the main motor of the press has seventy-f1ve horse power. 27 The new press not only has Improved the paper's typographical appearance, but has also enabled it to use color in its advertisements and multiple colors in news pictures. In an article entitled "The Build-up of Hsin Sheng Pao in the Past Nine Years" which appeared in the October 25, 1954, anniversary issue, the paper said that with the installation of the new press, the first of 1 ts kind in Asia, a remarkable progress in printing technique with regard to clearness beauty and speed was anticipated. In fact, the new press would mark a new ora in Free China's printing history, it added. 28 Attempting to fulfill a double duty, to inform the public as well as to serve the people, the Hsin Sheng Pao established a readers' service department in 1950. Its purpose is to bulld up a tie between the paper and its readers and to extend various services to them. The department offers travel service, sponsors recreational activities, contests, answers inquiries from readers and sounds out public opinion. Among its appreciable functions is a studio service where readers aan order prints

\section{Hsin Sheng Pao (Ninth Anniversary edition),} October 25, 1954 . 28 Ib1d. 
of pictures seen in the paper. 29

With regard to revenue, the paper's business report dated November 30, 1952, stated that the Hsin Sheng Pao, In the course of 1952 had made $N$ Tt\$ 0.50 (equivalent to two U. S. centa) at the fraction of every second. The same report predicted that this figure would nearly be doubled in 1953.30

In competing with other newspapers on circulation and public services, the Hsin Sheng Pro has endeavored to achieve the following:

(1) To sound out and reflect public opinion. The Hsin Sheng Pao considers that the foundation of democracy will not be solid if people are only told what to do, and not given a chance to express their opinions freely. Whether or not people can express thomselves to the rullest extent will depend on education to make their expression possible and effective. In viow of the fact that not all the poople are sufficlently oducated, the Hsin Sheng Pro is endeavoring to search for and to reflect public opin1on. 31

29Hsin Sheng Pao Business Report, October 25, 1956. 30 Ib1d., October 31, 1952.

3lIb1d. 
(2) To expand the circulation to the rural areas. As the paper has to make use of its limited available space to cover almost all the important events that happened in the world, the kind of language used in the paper tends to be concise and terse. As a resuli, the paper's circulation has been limited to large cities and among the Intellectuals. The Hsin Sheng Pao, however, is determined to reach the people living in the rural areas: farmers, laborers, fishermen and the like. This if fulfilled, w111 not only raise thelr educational status, but also -1llteep them informed of and interested in current news. To achleve this, the paper realizes that it is essential to make the language more readable to the less educated. Meanwhile, news about the activities of these people is to be given better coverage so as to make them interested in reading the Hsin Sheng Pao. 32

(3) To improve the contents. Editorially, the Hsin Sheng Pao supports and is responsible for circulating government policies. Articles written by experts and scholars to form and influence the formation of current cultural patterns appear dally under the "Spec1al Column." In treating international news, speed and accuracy are of utmost importance. Local and community news are to be

\section{Ib1d.}


given elaborate coverage, particularly in out-of-town editions. With regard to society news, the Hsin Sheng Pao emphasizes morality, denouncing the evil and praising the good. 33

After years of continuous progress, today the Hsin Sheng Pao, with 1 ts new printing equipment and new build1ngs, is a newspaper of the largest-scale on Talwan. 34 As an official organ of the Taiwan provincial government, the Ta1wan Hsin Sheng Pao has a dual responsib1lity: to convey government administrative orders to the people and to establish bond of understanding between the government and the people in addition to 1 ts basic journalistic mission.

The China Da1ly News

The China Da1ly News (Chung Hwa Jih Pao) is one of the four largest newspapers on Taiwan. It was founded by by the Kuomintang in 1946 at Tainan, a c1ty in the southern part of the 1sland. As most of the major newspapers were then, as asw, centered in the north, particularly in Taipe1, the establishment of a news medium in the south was needed. Recognizing the situation, the Kuomintang

33 Hsin Sheng Pao, October 25, 1945.

34central Da11y News, March 12, 1957. 
established a newspaper. The paper was the China Daily News which made 1 ts debut February 22, 1946.35 Han-Tsao Llang, now the president of the China Broadcasting Company, was the chalrman of the board of directors wile Kuan-Chun Lu, former government information official, was the first director. Although the Da1ly News 1s a party newspaper, 1t 1 s financed by both the party and the people. In fact, one fourth of the entire capital is invested by the local people, while the rest comes from the party. 36

When, at the end of 1948, the military situation on the China mainland was going from bad to worse and the government was losing ground, Director Lu resigned, leaving the Da1ly News in a state of confusion. 37 In October the following year, a stockholders' conference was called to reorganize the newspaper in order to put 1t back on 1 ts feet. Tao-Fan Chang, now the speaker of the Chinese Legislature Yuan (equivalent to the United States Congress) was elected chalrman of the board of directors, and ChengTung Lien, now the commissioner of the civil affairs department of the Talwan Provincial government, became the director of the Da1ly News. 38

\section{Ib1d.}

36Interview with P1n-Yan Hao, former director of the southern edition of the Chlna Daily News, February 5, 1958.

37 Ib1d.

36Pin-Yan Hao, A Business Report to the Board of Directors of the Chine Deilly Nerr, June, 1956. 
The Daily News' rival is the Hsin Sheng Pao. Both had competed vigorously for years on circulation. The Da11y News, besing in the south, attempted to broaden its circulation to the northerm part of the 1sland, wille the the Hsin Sheng Pao, publPshed in Ta1pe1, tried to spread 1ts circulation to the south. They both used rall transportation to ship their papers, but it was late in the afternoons when they reached their destinations. Later the Hsin Sheng Pao established a branch office in Tainan and published a southern edition there. The Dally News followed suit and stablished a northern edition with a branch office in Taipe1. 39 Competition had brought an increase to both papers c1rculations, but 1t was the readers who were actually benefited because in the process of competition both papers had to improve their contents and guality to attract more readers.

In 1955, Sheng-Fen Tsao, after returning from the United States where he studied at the School of Journalism of the University of Missouri, was appointed director of the nortifern edition Tsao, a gradiate of the National Chengchi (Political) University in 1938, was at one time personal secretary to President Chlang Kai-shek. 40

\section{Central Daily News, March 12, 1957. 40 Chine Handbook, $1954-55$, p.74l.}


Forelgn correspondents stationed in Talpel used to quallfy thelr dispatches home as being from authoritative sources. These so-called authoritative sources usually were Tsao. 41 The southern edition had been headed by PIn-Yan Hao since 1950 unt1l he left in 1957 for further study in journal1sm at the University of Missour1. Y. B. Hsu, a veteran newspaper man, oducated at the National Chengch1 University, succeeded Hao.

Like most of the other Chinese newspapers, the rirst page of the Dafly News carries domestic or Important forelgn news. The second page is predominantly occupied by forelgn news and the third has local news. Page four provides financial and sports news. Page five contains community news complied from the reports of stringers. Page s1x 1s the entertainment page w1 th 1 ts space predominantly occupled by movie advert1sements. The entertalnment section contains light, famillar essays, foullietons, serials and comic strips.

The contents of the northern and southern editions vary primarily only in local news and advertisements; also the southern edition has more human interest stories than the northern edition. However, the chlef difference that makes the southern edition more profitable than 1 ts sister

4linterview with Pin-Yan Hao, February 7, 1958. 
paper, lies in 1 ts community news. As the three neighboring cities, Kaoshiung, Plntung and Chlayi, are prospective markets, the Dafly News, in order to expand its circulation to these c1tięs, has set up a system by using three different editions, each carrying the news slanted to meet the interest of the readers in that particular c1ty. As people are interested in their local affairs, their own activities and their own news, this device has greatly boosted the total circulation of the southern edition. In fact, an increase of 6,000 coples was added to the paper's circulatio following the adoption of this method. 42 This method of increasing out-of-town circulation was introduced by P1n-Yan Hao in 1952, two years after he became director of the southern edition.

The two editions of the Daily News, though varying somewhat in news content and advertisements, carry the same editorial. Usually the editorial is written in the south and transmitted to the northern office by telephone or telegram. The sameness of their editorials further indicates that both editions arially one paper supporting the same editorial policies. 43 Another important feature of the editorial section is the special articles. Trans-

42 Ib1d.

43Ib1d., February 11, 1958. 
lated from foreign magazines or newspapers or written by experts in the form of commentaries, these articles cover a wide range of subjects such as: politics, international affaim, educational problems, science and travel.

The basic principles of the news policy of the China Daily News can be summarized thusly: ant1-communiam, freedom, democracy, social reform and scientiflc developmonts. 44 These principles are adopted in the Daily News' editorial policies.

An editorial published on October 10, 1957, the Chinese National Anniversary Day, 1llustrates the paper's editorial policy. On such a day the Chinese newspapers have made it a rule to express their views toward big 1ssues or to relterate their stand on editorial matters.

There were two editorials in the Daily News in its October 10, 1957, 1ssue. The topics were entitled: "A Message for the Celebration of the National Day" and "The New Mission of the Elghth Convocation of the Kuomintang."

The first editorial said in part:

Today is the National Birthday of the Republic of China. Forty-six years ago, the Nationalist Party under the leadership of our National Father, Dr. Sun Yat-sen, overthrew the Manchu Dynasty and founded the Republic of China. Since then, the party has devoted itself to buliding the nation up along the IInes of democracy.

44Pin-Yan Hao, Business Report, June, 1956. 
The history of the Republic of China has been written in blood and tears. Within the period of forty-six years, we have confronted the ruthless warlords, the Japanese military aggressions and the rebelilion of the Chinese Communists. These unfortunate factors have made wat our nation is today. But the freedom and independence of our nation, the demecratic way of life, gind the promotion of our living standard are the wishes of the poople as well as the assertions of our National Father. 45

The editorial concluded by saying, "If we belleve these assertions truly, and strive for them positively, we will eventually be able to destroy Communism and obtain final victory."

The editorial under the the E1ghth Convocation of the Kuomintang" had this to say:

It was the Nationalist Party, under the guidance of Dr. Sun Yat-sen, that overthrew the Manchu Dynasty and founded the Republic of China. It was the Nationalist party under the leadership of President Chiang Kal-shek that stampeded the warlords and established the National government. It was again the National government under the leadership of President Chiang that fought against the Japanese domination and obtained the final victory. Yet it was also the National government that lost the whole China mainland to the Communists. It is therefore the duty of the Nationalist party to destroy the Communist tyranny, to recover the Chinese malnland and to reconstruct the nation in accordance with the Three People's Principles.

A great number of the colleagues of the Nationalist party had dedicated their lives to the cause of the revolution in overthrowing the Manchu Dynasty, in crushing the ambitions of the warlords who stood in the way of a unified Chine and in resisting the Japanese aggression. What was the purpose of these men sacrificing themselves? It was all because they

45A translation from the China Daily News (Southern edition), October 10, 1957. 
belleved that only the Three People's Principles can save China and that they therefore struggled and sacrificed their lives in order that these principles could be real1zed.

The purpose of the Three People's Principles is to constieute a government which is of the people, by the people and for the people. Now that the eighth convocation of the Nationalist party is being held, we hope it will work out some practical measures to recover the China mainland and to guide the nation toward realizing these principles. 46

The daily circulation of the northern edition is around 15,000 wile the southern edition has a c1rculation that approximates 25,000. Although there are no special editions on Sunday, the Sunday 1ssues of the northern and southern editions sometimes reach 17,000 and 30,000 cop1es respectively. 47

The United Daily News

The United Da1ly News 1s the result of the amalgamation of three morning newspapers, the People's Daily News, M1n Tsu (national) Pao and the Economic Times. 48

The merger came in 1951 when the three papers were near bankruptcy in the face of rising production costs, slumping circulations and keen competition by other news-

1957 .

46China Daily News (Southern edition), October 10, 47 Pin-Yan Hao, Business Report, June, 1956. $48 \mathrm{Ch}$ ina Handbook, 1944-55, p.190. 
papers on Taiwan. Ting-LI LIn, Tien-Wu Wang and Ngou-Nien Fan, publishers respectively of the People's Daily News, Min Tsu Pao and the Economic Times met one day and decided that a united edition published under the partnership of the three falling newspapers probably would bring about a better future for their journalistic ventures. Because the merger would cut down production costs, eliminate extra personnel and moreover, they could concentrate their brains on the publishing of one newspaper instead of struggling individualiy for existence.

The 1dea of merger was of course a but the three publishers decided to try it. Thus the merger was effected and the combined efforts of the three men material1zed on September 16, 1951, when their first 1ssue made its appearance. It was then named the United Edition with the titles of the original three newspapers compressed in the new nameplate. Later, however, it was changed to the United Daily News and in 1958 the titles of the three partner papers were deleted. This signified that their union has since become permanent.

The merger has brought a new life to the newspaper. Indeed, the United Daily News is an entirely new journalistic venture in the history of the Chinese press on Talwan. Organizationally, the paper was made into a corporation. The three partners alternate in the posts of president of the board of directors, publisher and director 
As a corporation, the paper divided its stocks into four equal shares, one for each of the three partners and the fourth is distributed to its employees as a bonus every year. 49 The bonus awarding system is designed to make the employees feel that they are part of the business and that the success of the paper concerns all the staffs of the paper.

The United Daily News is a lively, vigorous and attractive newspaper. Its contents are compact and varied. As a newspaper slanted to the welfare of the ordinary people, it lays great emphasis on society news, economic and financial news. The emphasis on crime, sex and social scandals has brought the paper a name as an advocate of sensationalism. While there is no evidence to prove that the paper owes 1ts popularity to its rather famous society news, it is certainly evident that soclety news is one of the main features that distinguishes the United Daily Ners from other major morning newspapers.

Good coverage of economic and financial news, nonetheless, is another Importang feeture of the tnited Daily News. The paper is very popular among commercial and industrial circles. In fact, the usual place for editorial, national and international news in most newspapers,

49The United Daily News, a brief introduction to the paper, obtained through Teh-Wei Fu, April 5, 1958. 
page two, is devoted to financial news in the United Daily News except for the bottom of the page which is occupied predominantly by classified advertisements. The page of nomally contains a dally report of the Taipel market, listing the prices of commodities, food, chemical materials, medicine and construction materials, A small but compact section deats daily with the fluctuation in the Talpel stock market. The fish market and the commercial situation of Kaohsiung, a port.at the southern t1p of the 1sland, are regular entries of the page. A column ent1tled "A Casual Talk on Economy" virtually has become the finan-so cial page's editorial. In pointing out to the government the severe consequence that might result from the unrealistic promulgation of regulations governing financial and monetary affalrs, the column sa1d on September 13, 1957:

In the past regulations governing financial and monetary affairs were drafted without negotiating with the physical conditions. Therefore when it came to execution, they confronted opposition and hazards. As a remedy, the regulations were amended with orders so as to rectify the mistakes. However, when too many patches vere made on the original regulations, implementation would become even more cemplicated. The more complicated they became, the less would they be adopted....As the effects of regulations concern the welfare of many, they should be delineated $w$ th greatest care right from the beginning....

In response to the financial authorities' plans to expand overseas market for industrial products, the column had this to say in 1ts September 11, 1957 talk:

Industrial products should first be distributed to meet the domestic demand. Exportation should come 
only when there is an extra surplus after domestic demand is met. The standards for products of home use and exportation vary. The question 1s now whether the native product's price and quality are on a par with the international standard. If the answer is jes, exportation is justifiable so long as there is a flow of supply. However, if the answer is a negative one, there 18 no use of enforcing the expansion plans. Even if the expansion should be done by force, 1 t would not work.

The United Daily Nerg 18 said to have risen in prestige following the publication of a series of editorials in June, 1954, discussing the political situation, past and present, in China. The oditorials, all ont1tled "New Cabinet, Old Problems," were published when Premier 0. K. Yui 50 took office. The outspokenness and boldness of the United Daily News in publishing these 1mportant articles were said to have alded in bringing the paper into Its present position as one of the major morning newspapers on Talwan despite its sensationalism in the treatment of soclety news. 51

Carlton Culmser, head of the journallsm department at Utah State Agricultural College and visiting professor at the Graduate School of the National Chengchl University, Ta1pe1, for one year,had this to say

500. K. Yu1, a graduate of St. John's University, Shangha1, was mayor of Shangha1 in 1937, Minister of Finance 1944-48, Govenor of Contral Bank of China 1948-49, chalrman of board of directors, Bank of Talwan 1952, Govenor of Taiwan 1953-54.

51 Interview with Ho-Chin Peng, March 20, 1958. 
News: 52

The vernacular United Daily News spoke out even more boldly than Kung Lun Pao [a private daily]. The directors of the paper are listed as Lin Ting11, Fan Ngou-Nien, and Wang Tien-wu. Because the frest-named was recently convicted of selling foodstuffs 1llegally (this case had no connection with his publishing activities), the paper is in a dubious sort of Ilmelight. But al though the dominant influence in the paper is said to be exerted by Kuomintang members, criticisms of government have been forthright.

The paper has, for example, criticized certain Chinese diplomats, not hesitating to name names. After praising an able type of man, the paper turned to the other extreme. The writer named examples of each, and then declared of the lattes sort: "They get into diplomatic service through political channels or special relations. Such people should not be entrusted with important diplomatic posts. They are good for nothing...."

In response to President Chlang Ka1-shek's calling for criticism on October 15, 1956, the United Da11r News carried an article written by Heng-Ta1 Tu, an economist. The article, urging the government to restore free enterprise, was summarized in the East and West's December, 1956, is sue: 53

Tal called upon the government to restore free enterprise to the nation's economy. Mr. Tal lamented the unbalanced dependence of the economy on U. S. ald. Tai indicated that the four year Economic Plan which ends this year has not succeeded because, while production has risen considerably, it has not kept pace with the growth in population in Taivan. Tai pointed out that government regulation had failed in

52 Journal1sm Quarterly, Summer, 1956.

53East and West (a Sino-American Cultural and Economic Association publication), December 1956, p. 16. 
its efforts to control the production and distribution of cement and coal, had caused overproduction in various protected industries, and had been unable to attract forelon capital. Mr. Tal saw in freo enterprise the answer to Taiwan's economic problems. The writer defined free enterprise as including the freodom to start business, acquire the means of production and to market the product. Tai advised the government to take two steps to improve the business situation; one, control the price structure; two, prevent the rise of monopolies.

The United Daily News' news pollcy is based on public appeal, free expression and is slanted to the taste of the ordinary people. Local news rather than international news is given greater emphasis. In adition, its language is slanted to the educational background of the average people.

The paper maintains a full-time correspondent in New York who regularly airmalls back features and special articles about the current political development in the United Nations as well as in the United States. Off and on he writes about the various aspects of life in the United States. The paper also has correspondents in Tokyo and Paris. For out-of-town news, the United Da1ly News maintains 150 correspondents and stringers in thograrious cities and towns on the island.

The Un1ted Da1ly News has a lively supplementery page. Contents of this page are entertaining in nature. Short stories or serials written by local writers or translated from forelgn publications, movie reviews, pictures of local and Hollywood movie stars and their 
stories are the usual tenants of this page. Every Monday there is also a women's page entitled "Women's Life." Articles in this page deals mostly with love, family, child care and housekeeping.

Although the United Da1ly News caries no comic strips at present, it frequently reprints political cartoons from foreign newspapers such as the San Francisco Chronicle and the London Da1ly Ma1l. For each cartoon used the United Daily News gives credit to 1 ts source. Advertising revenue is one of the chief elements that has brought the United Daily News to 1 ts present prosperity. Unlike other major morning newspapers on the 1sland, the United Daily News devotes a third or more of Its front page to advertising. Except on page three and page six, which are occupied respectively by local, society news and the supplementary page, every other page has advertisements. Moreover, page five is given over exclusively to movie advertisements. Red color is extensively used in the advertisements. Although this makes the page look in poor taste typographically, nevertheless the advertisements are eye-appealing.

Circulation of the United Daily News has been growing rapidiy since the amalgamation. Although an accurate figure is not available, the United Da1ly News is said to have a da1ly circulation of approximately 50,000. T1-Wu Wang, the present publisher, said on September 16, 
1957, on the occasion of the paper's s1xth anniversary: "Not only outs1ders were surprised by the unexpected progress we have made, but even we ourselves could not belleve our om achlevements." Liberal views, outspokenness, good coverage of economlc news, popular appeal, boldness in exposing background information about politics, emphesis on local news, and 1 ts concern over the welfare of the ordinary people are the elements that have paved the way to prosperity for the United Da1ly News.

The Cred1t Informat1on (Cheng Hsin Hsing Wen)

The Credit Informat1on, similar in nature to the Wall Street Journal, 18 the one and only rinancial newspaper on Talwan. Popular as market gulde among the Chinese merchants, it is one of the two largest privately owned dallies on the 1sland, the other being the United Daily, a paper orlginally consolidated from three Independent da111es.

Founded in 1950 and financed by the Committee on Materials Supply whder the Talwan Provincial Government, the Information was an officlal bulletin intended to keep the commercial circles abreast of both the economic and financial situation on the 1sland. 54 The Information, when f1rst published, was mimeographed, hlghl1ght1ng the

54 The Central Da11y Ners, March 12, 1957. 
da1ly financial developments with particular interest in analyzing the maricet and in the fluctuation on commodity prices. In March the following year, the paper was suspended by the committeo. However, Chl-Chung Yu, an Engl1sh-educated student and former staff member of the Committee, came to the rescue. Yu ralsed enough money to take over the paper and continued 1 ts publestion with himself as the publisher. 55 Thus the paper's ownership was transferred from official to private.

When Yu first took over the Information the paper did not face a prosperous future. Financially, it now lacked the former backing of the provincial government. Furthermore, it had to compete with the Economic Times, a financial newspaper in regular format since 1947. However, the T1mes was short-lived and was consolidated in 1951 with two other newspapers to become part of the present United Da11y News. 56 The consolidation left the Information as the only financial newspaper on Taiwan.

Blessed with no competition on the one hand and through the efforts of the business-minded publisher on the other, the Information strove hard to build itself a reputation as a reliable source of financial information.

55 Ibid.

56 Ib1d. 
In 1954, the Information for the first time became a newspaper of regular format with four pages while 1t attempted vigorously to improve 1ts contents.57 To make the paper distinctively different from other newspapers, Publisher Yu established a quotation division to deal exclusively with the delly market situation, reporting the commodity prices and analyzing the market fluctuation. The addition of this division undoubtedly promoted the paper's position as an authoritative financial newspaper. 58 The year 1955 marked another expansion. The Information increased from four pages to six pages, thus joining the ranks of the other six-page dallies. Because of a shortage of newsprint, six pages is the standard size for dallies, under government regulations.

The title of the Information is self-explanatory with regard to 1 ts contents. In fact, colimodity prices, forelgn exchange rates, market fluctuation, stock markets, industrial achievements and the international market situation are the major features of the Information's contents. However, in to meet general taste, a dally society page, a dally comic strip and a plcture-page in-

57 Ib1d.

58 Interview with C. C. Cheng, former reporter of the Credit Information and now a graduate student at the Un1versity of Kissouri, February 5, 1958. 
sert, whlch appears regularly with the Mônday paper, have been added. These new additions make the paper more 11vely and amusing to read. Ed1torlally, the Information advocates industrialization and economic reconstruction on the 1sland and calls for Improving the l1velihood of the people.59 Desplte its declared pol1cy, the paper is an advocate of sensational1sm. "Soclety news, crimeiand sex are usually played up to whet the taste of 1 ts readers. The Information is also act1ve in launching campalgns. In December, 1957, for example, the paper sponsored a focal movie contest to select the best Taiwan dialect movies as an act toward promoting local 1ndustry. The act was ong of the promotion techniques used to attract the public's attention and also to build up 1 ts circulation and advertising revenue. 60

Like most other newspapers, the Information's revenue comes from two sources, circulation and advertising Both sources occupy equally important positions in the paper's financial standing. The United States economic ald programs perhaps have indirectly helped to build up the paper. For w1th the advent of the economic a1d, Industry and commerce flourlshed. The result was that more adver-

59 The Central Da11y News, March 12, 1957. 60 Interview w1 th C. C. Cheng, February 5, 1958. 
tising space was demanded of the paper, and that more people became interested in the economic and industrial expansion on the 1sland. 61

The Informat1on is a multi-colored newspaper using red, black and blue 1nk. Printing is don on an old Japanese-made rotary press. As 1 ts printing equipment is not as modern as that of the other large dallies, typographlcally there is much room for 1mprovement. However, the fact that the nameplate is red and 1 ts advertisements are red further causes the general make-up to look uneven and lack nestness. The use of red color in advertisements sults the taste of the merchants who feel that red is more eye-appealing. Unfortunately, the appeal is made at the sacrifice of good taste in typography.

Organizationally, the Information is a corporation, but in effect it is under the control of the publisher who, besides delineating the paper's policy, is responsible both for the printing and business side of the paper. 62 The Information has about 200 employees distributed among 1 ts three departments: the news-editorial, business and mechanical. However, a majorlty of the employees are typesetters, an irromediable situation common to all the

\section{${ }^{61}$ Ib1d. \\ 62 Ib1d.}


Chinese newspapers on the island.

Under Yu's continuous management, the elght-year-

old Information Credit has become a reputable newspaper in Free China, having a good coverage of general news while remaining basically a flnancial paper. The paper is wellcirculated among the business and industrial circles, which credit it with comprehensive news reporting and : rellable, up-to-date financial information. 63 While a definite circulation figure could not be made available, the Information was sa1d to have printed 25,000 copies each day through July, 1957.64

Kung Lun Pao

The Kung Lun Pao is a private morning daily pub11shed In Ta1pe1. It was founded on October 25, 1947,65 by a Talwanese, Wan-Chu L1, who recelved his education in France at the University of Paris. Li has served as deputy speaker of the Taiwan Provisional Provincial Counc1l, member of the Talwan Provisional Provincial Assembly, director and chalrman of the board of directors of Taiwan Hsin Sheng Pao. 66 His association with the political

63 entral Da11y News, March 12, 1957.

64Interviow w1 th C. C. Cheng, February 5, 1958. 65Central Da11y News, March 12, 1957. 66 Chlna Handbook, 1954-55, p. 717 . 
forum on Taiwan has made him well acquainted with the various aspects of political affairs on the island. In addition, his early connection with Hsin Sheng Pao as first director of the paper was helpful in preparing him for operating a private newspaper, the Kung Lun Pao.

As the Kung Lun Pao, meaning public commentary, is published by a Talwanese, it is essentially a local newspoper. As such, society and financial news as well as local affairs are given greater attention. However, the paper is also regarded as one of the more outspoken critics of the government. 67 since Li is a member of the Young China Party, one of the two minority parties in the Republic of China, the Kung Lun Pao frequently reflects the opinions of the party, although it is not an official organ of the party. Nevertheless, the paper is both bold and straightforward in criticizing the government.

In response to President Chlang Ka1-shek's request for critic1sm on October 15, 1956, for example, the Kung Lun Pao carried an article written by Mu-Chia Sun, a fournalist, which was summarized in the East and West, an English-language monthly magazine published in Taipe1, as follows:

Mr. Sun observed that this is the first time in his more than thirty years of political activity in China that the President has appealed to public opinion. The growth of bureaucracy in China has

67Carlton Culmsee, "How Free Is the Press in Free China?" Journallsm Quarterly, Fall, 1956, p. 495. 
been one of the chief deterants [sic] to political progress, commented Mr. Sun. He criticized the President, in part, for assuming the full responsibility of government control and not permitting subordinates to make policy decisions within their own spheres of activity. Sun also criticized the subordinate government leaders for not assuming their responsibilities. Mr. Sun recommended the following measures to improve the situation:

(1) lift all restrictions on freedom of speech, (2) release those who have been imprisoned for blunt speech, (3) establish an investigation bureau of public opinion, (4) nominate Kuomintang candidates by party free election, (5) encourage opposition parties, (6) convoke the National Salvation Conference, (7) establish a projecting council to reviow and initiate government policy.

The Kung Lun Pao is frank in commenting on public affairs. In criticizing the decline of enthusiasm in local elections in 1956, the Kung Lun Pao asked bluntly in an editorial if the apathy were not due to the fact that Kuomintang candidates were usually unopposed. 68

As another example of the paper's boldness in revealing administrative inefficiency, the Kung Lun Pao based an editorial on the "Yellow Ox" or movie ticket scalper, declaring that existence of the problem reflected administrative inefficiency. It asserted, "Nobody dares to or can take thorough going measures to stop the yellow oxen...."69 It further added:

This reflects the many handicaps in administrative inefficiency. The handicaps show that something is

$$
\begin{aligned}
& 68 \text { Ib1d. } \\
& 69 \text { Ibid. }
\end{aligned}
$$


out of tune with the many efforts at progress now on in Free China. If we do not try to cure this disease which makes one afraid of duties, afraid of reforms, unable to concentrate the respons1bility but fond of perfunctory things, no troubles can ever be solved smoothly. Yellow oxen are just one simple example. 70

The Kung Lun Pao is the lowest-circulated among the major Chinese-ianguage morning papers. The present daily circulation is estimated at 5,500. The low circulation figure neturaliy affects the paper's advertising patronage. While no statistics regarding its advertising revenue are available, 1t is apparent that the Kung Lun Pao can hardly compete successfully with other majox newspapers such as the Central Daily News, Hsin Sheng Pao and the United Daily News. Its low advertising revenue may be attributed in part to the fact that the Kung Lun Pao does not use red color in its advertisements, which is a vogue amorof almost all other Chinese newspapers, including some of the evening newspapers.

Typographically, the Kung Lun Pao is not attractive. Because of the lack of modern facilities, its printing is not on a par with that of other newspapers. Despite its physical weaknesses, the Kung Lun Pao is highly regarded for its outspokenness, stralghtforwardness and boldness in criticizing the government and in pointing out

70 Ib1d., pp. $495-496$. 
administrative defects. In a country which is trying to learn the ways of democracy, the existence of such a newspaper as critic of the government administration is necessary and highly desirable. 


\section{CHAPTER IV \\ ENGLISH LANGUAGE DAILIES}

The Chine Nerrs

The advent of English-language newspapers on Taiwan was in answer to the need caused by the increasing number of diplomatic missions to Free China. The forelgr population, particularly American, increased steadily in the years after 1951 when Taiwan's strategic value in the Pacific Ocean was recognized by the free world in the face of successive Communist threats in that area.

The first answer was the China News, a privatelyowned daily published by the China News and Publication Service. Founded in 1949 by a group of refugee newspapermen who fled to Taiwan in the wake of Communist seizure of the China mainland, the newspaper is mimeographed and compiled in the form of a bulletin usually containing twentyfive or more pages. Stanway Cheng, a graduate of the School of Journalism of the University of Missouri (A.M., 137) since its founding has been director and editor of the paper. Carrying under its name-plate the slogan, "An enlightened public is the best security of a nation," It had a pald circulation of 5,500 up to December, 1957.1 Sold at NT\$2.00 a copy (equivalent to a United States

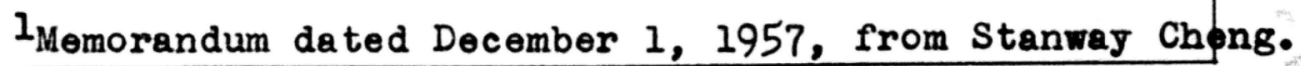


nickel), the Chine News is the highest-priced newspaper on Taiwan.

It used exclusively news dispatches from the Assoclated Press and the Routers at 1 ts start, but later when its circulation increased, it began to carry domestic news and a commentary. English translation of the major Chinese newspapers' editorials also appeared daily in the paper. ${ }^{2}$

As all the 1mportant newspapers in Talwan are mornIng papers, the China News, boing issued each day in the early afternoon, carries much fresher news than any of the other newspapers in Talwan. On this account, it enjoys popularity among the island's English-reading public which consists of both forelgners, mostly Americans, and Chinese Intellecturls.

Because of 1 ts independent and objective stand, the China News has often been regarded by both the forelgn population in Talwan and the overseas Chinese as a mirror of a free but responsible press in Free China. The Chine News has often been critical of governmentypolicies and administration, jet it fervently supports the nation in its overall policles of democracy and anti-communism.

"I must say ours is a very small paper but we are aggressive in our reporting and outspoken in our views. Of

${ }^{2}$ Central Da1ly Ners (Ta1wan), March 12, 1957. 
course, we are warmly supporting our government when there are big issues at stake. Off and on, we offer criticlsms and suggestions. They are all done in good faith and with the best of intentions," sald Stanway Cheng, the pub11 sher. 3

Good coverage of news, objective reporting and a fair and outspoken editorial polas have made the China Newis a reliable and authoritative source of information about Chinese affairs. Many forelgn correspondents stationed on Talwan have made it a practice either to quote or use the Chine News stories in their entirety in their dispatches. The American Embassy, the United States Information Service, the Mutual Security Mission of China under the International Cooperation Agency as well as other forelgn and diplomatic missions in Taipel have depended on the China News for background information about China. The American Embassy alone sends many copies of the China News to the State Department through 1 ts diplomatic pouch everyday. 4

The China News maintains an overseas edition which is alrmalled daily to all parts of the free vorld. The alrmall edition, consisting of both domestic news and

3Letter from Stanway Cheng, dated December 1, 1957. 1957 . 4Memorandum from Stanway Cheng, dated December 1, 
commentaries is sent out in large numbers by foreign missions to report the state of affairs inside the Republic of China to their home governments. Chinese organizations maintaining branch offices abroad alsc use the airmail edition to keop their staffs informed of what is going on back home. 5

The alrmall edition has been used extensively by the Chinese News Service in New York City which provides a bulletin service to American newspapers and interested organizations and individuals. The Chinese News Service in London also uses the alrmall edition as a blueprint in its information service. Both news services are under the direction of the Government Information Office in Taipei. 6 The news carried by the China News is broadcast daily by the Volce of Free China, a government-operated broadcasting station, to the outside world. The Central News Agency uses the China News for its dally newsist to Southeast As1a. The U. S. Armed Forces Radio Station in Ta1pe1, as well as other private broadcasting stations using the English language, also rely on the facilities of the China News in their news programs. 7

5 Ibid.

6Ib1d.

7 Ib1d. 
In comparison with the c1rculation status of other 1mportant newspapers in Talwan, the China News probably is the least-c1rculated newspaper. Although it carries both display and classified advertisements, the advertising revenue 1s low. This is because of the handicap of mimeographing which physically limits the attractiveness in advertising make-up so easily done in awspapers of regular format. Therefore, at present the paper is barely self-supporting. 8 Even so, the paper is nevertheless a vigorous medium of free press. Director Cheng, in commenting on the financial status of the paper, says, "Be1ng self-supporting and Independent is the best asset of the China Ners."

Al though the Chine News is published in a mimeographed format, 1 t is a complete newspaper in nearly every other way--w1th news, editorlals, advertisements and a da1ly financial report. It is not, of course, able to carry plctures. The China News, however, in 1ts long-range plans, has under consideration publishing in regular newspaper format. The deterrents to such an attempt at present are basically financial; as director Cheng polnts out, "The economic conditions on Talwan and the st11l $11 \mathrm{~m} 1$ ted

8Letter from Stanway Cheng, dated December 1, 1957. 9 Ib1d. 
circulation figures tend to discourage us from embarking on a more ambitious adventure." 10

Of all its limitations, the China News, one of the only two English dailies in Taiwan is "a popular and influential news service in Free China."Il

\section{The China Post}

The first regular-sized and printed English-language newspaper on Taiwan is the China Post. It was founded by a husband and a wife, Mr. and Mrs. Y. P. Huang. Mrs. Huang, a graduate of the School of Journalism, Columbia University, is the publisher, while Mr. Huang, a journalist trained in Tokyo's Meifl University, handles the business side of the Post.

The Post was founded with an 1dea plus enthusiasm. The 1dea first emerged when the Huangs, having moved to Talwan after the Communist seizure of the China mainland, realized that on English-language newspaper would be of great service to the English-speaking population on the island, then Iimited to about one thousand, in familiar1zing them with the conditions in Free China. The 1dea materialized when the Huangs and their friends scraped

10Ibid.

${ }^{11}$ China Handbogk, 1956-57, p. 216. 
together the equiplent of obout $\$ 5,000$ (U.S.) in the fall of 1952. W1th th1s meager cap1tal, they rented a flat-bed printing press and hired a dozen typesetters. After rogistering with competent government authorities, "The only Engl1sh-language newspaper In Free China" as the Post carries underneath 1 ts nameplate, made 1 ts debut on September 3, 1952. 12

The first 1ssues of the Post were poorly edited, inferiorly printed, and full of typographical errors. However, the combined efforts of some thirty-nine people, using primitive methods, managed to keep the paper alive. Sixteen of the thirty-nine people were not on the Post's regular staff. Of the twenty-three regular staff members, fifteen were typesetters, two were pressmen and the rest were proofreaders, clerks and office boys. The editorial staff consisted chlefly of "volunteers" who were enthus1ast1c in helping to publ1sh an English-language newspaper, the flrst of 1 ts k1nd on Ta1wan. The "volunteers" wrote, translated, and edited. Some worked two hours a day of longer and recelved elther a nominal allowance or practically nothing for their work. 13

The person responsible for splicing the paper

12. Interview with Helen Yu, sister of the Post's publisher and former reporter of the Post, December 26, 1957 .

13 Ib1d. 
together was Publisher Nancy Huang. Working as many as sixteen hours a day, she did all the page layout and handled most of the advertising and circulation matters. In addition, she covered news beats during any available spare time. When the paper was begun, a forelgn news agency reported that "the sponsor of the new dally is supposed to be David Kung, son of a prominent Chinese millionaire who was finance minister during the war, Dr. H. H. Kung." The agency further pointed out that though the reports "could not be confirmed, the information is said to be quite reliable." 14

In reply to the report, the Post made the following statement:

1. It is herewith announced that China Post is an independent newspaper enterprise. Its entire capital comes from the investments of some of the people who are now working on the China Post.

2. China Post had one 1deal which it will try to IIve up to--to advocate the freedom of press.

3. Staff members of the China Post absolutely refuse to be used as the publicity instruments of any Individual and of any private or public organizations.

4. For our financial backling we completely rely on our business. This publication will be suspended if we cannot make it self-supporting. 15

The fact that a newly-founded newspaper had to

I4CNA-INS dispatch in China News, Septembor 3, 1952 15China Post, September 8, 1952. 
declare that "This publication will be suspended if we cannot make it self-supporting" alone helps to prove that the Post is a private, independent paper free from any strings.

The Volce of America on April 28, 1953, in introducing the China Post to 1ts listeners, listed the difficulties confronting the paper as follows:

First of all, there was a shortage of Englishlanguage editors and writers.

Then, there was no linotype in Formosa....

A third important reason was the uncertainty of revenue which can insure the financial independence of a newspaper. The typical newspaper in the United States depends on advertising for the bulk of 1 ts revenue. In Formosa, Industry had not yet learned to rely on advertising to sell, thus no nerspaper could count on advertising as a major source of revenue.

It was through trial and orror that Publisher Huang and her colleagues challenged the difficulties which to a newly established forelgn-language paper were almost never ending and continually arising. However, the efforts they put into the enterprise eventually bore fruits. Financially, the post came out of the red in May, 1955, and business flourished and circulation grew. 16

True, there was a shortage of English-language editors in Taiwan. However, the Post has in the course of

16Interview with Helen Yu, December 27, 1957. 
the years since its founding recruited several competent English editors and writers on the 1sland. The editorin-chief, C. J. Chen, (B.J. '24) for example, is a graduate of the School of Journalism of the University of Missouri. Other senior editors on the Post's editorial staff are mostly former students in America, familiar with the American way of newspapering. The Post also has an American columnist, Joe Brooks, on its staff. Brooks for five years has written the column "From a Yankee's Notebook," a gossip column.

The Post's type is set by hand. There are thirty compositors who work in two shifts. It takes about nine hours for them to complete a day's work. An automatic typecaster casts all the type neoded for the paper at a speed that allows complete replacement of new body type every five days, and of most headline type every two weeks. The Post has recently bought three linotypes, but they are used only for job printing at present. As the use of a Iinotype would greatly change the format of the paper, and as there is a shortage of trained linotype operators in Talwan, the Post has hesitated to use 1 ts new equipment for newspaper production. 17 Printing is done on a $211 / 2$ Inch Marinoni rotary press which can produce approximately

17Ib1d. 
8,000 copies an hour.

Thirteen months after its debut, the Post was able to alter 1ts size from a half sheet of two pages to a full sheot of fourapares. By adopting small body type and an extremely condensed ariting style, the editors of the Post have managed to present a fair and complete coverage of current events, both national and international. The Post depends largely on the United Press for 1ts international news; th1s 18 supplied by teletype. News through Morse code of the Associated Press, the International News Service and the Central News Agency of China are also used, but to a lesser degree. Most of the local and state news 1s gathered by the Post's own reporters. An average of one-fifth of the four-page Post is occupied by advertisements. The remaining columns are devoted to editorial matter including one or two editorials, feature and special articles, news, two comic strips, "Beetle Bailey" and "The Flop Family." New attractions, such as news pictures, political cartoons have also been added to the paper. The expansion from two pages to four pages and the improvement in quality necessitated an increas in production costs. Yet, advertising did not keep pace with the increasing circulation because of the limited size of industry and trade on Taiwan, and because Chinese merchants still did not believe in the effects of advertising. Thus, for more than twelve months the management, confronted 
with the mounting expenses of the news-editorial department on the one hand and the small income from advertising on the other, simply could not make financial ends meet. For a time the accumulated debts seriously thregtened the existence of the paper. 18

Although the situation was bad, the prospects were not dim. The four-year reconstruction plan launched by the Chinese government with the support of the United States aid program, starting in 1953, began to show good prospects for the island's economy. 19 The government was then aware that an economic and industrial bulld-up was mandatory in transforming the island into a stronghold in defiance of Communist aggression. With economy strengthened, new business began to boom, which meant more advertising revenue to the Post. Meanwile, with the strategic value of the island further recognized as essential to the chain of defense in the Pacific, American military and diplomat1c personnel increased in number. This meant more circulation to the paper. In fact, by the end of 1955 , advertising revenue had doubled that of 1953, and circulation had Increased to 6,000, also doubling the 1953

$$
\begin{aligned}
& 18 \text { Ib1d. } \\
& 19 \text { China Handbook, } 1954-55 \text {, p. } 377 \text {. }
\end{aligned}
$$


record. 20

At this point, the management was faced with

another serious problem. The low-speed, flat-bed printing press was unable to meet the demands of 1ncreasing circulation. Yet the profits made did not encourage the purchase of modern equipment. After montbs of careful planning and negotiation, however, a loan equivalent to $\$ 10,000$ (U.S.) was made ava1lable to the Post from the Bank of Talwan. Th1s plus the Post's own savings, enabled 1t to buy an old but more efficient printing press and a new bullding providing better working conditions for the staff. Although the newly bought rotary press could meet the increasing circulation, it left much to be desired so far as the quality of printing was concerned. The printing was not sufficiently clear and the finished product was below par in comparison with the accepted standards of a modern Amer1can newspaper. 21

The year 1956 was marked by expansion and reorgan1zation. The business department, for example, which had been limited to a few clerical assistents before, was strengthened with the addition of a clrculation mandor who took positive measures in increasing circulation. A

20Interview with Helen Yu, December 28, 1957. $2{ }^{2}$ Ib1d. 
general manager was appointed to take charge of the overall business side of the Post. Business and circulation agenc1es were established in Tokyo and Hong Kong as preliminary steps in expanding business abroad. Plant for establishing agencies in America and the Philippines were also contemplated. An example of the Post's forelgn expansion in 1957 was the signing of a year's advertising contract with two American f1rms, the Winston Cigarette Company and the Trans-Oceanic Alrways of California.22 The present c1rculation, as of December, 1957, was $10,000.23$ Th1s 1s considered a falrly good-sized c1rculation since the Post is a forelgn-language newspaper. It publishes seven days a week, but w1 thout special Sunday editions as most of the American daliles do. The Post's readers consist mostly of the forelgn population on Ta1man, mostly Americans, and a large number of influential Indiv1duals, government officials, civic leaders and intellectuals who find it more convenient to read international news through an English medium. 24

22 Ib1d.

23Ib1d.

24 Ib1d. 


\section{CHAPTER V \\ EVENING NEWSPAPERS}

There are four evening newspipers on the 1sland of Talwan. All of them are published in Talpel with the exception of Chung Kuo (China) Evening News which is a local paper in Kaohsiung. The three Talpel evening newspapers are: Tah Hwa (Great China) Evening News, Tze L1 (Independence) Evening Post and Min Tsu (National) Evening News. 1

At first the evening papers did not enjoy good circulations. Later, the increase in population following the retreat from the mainland gave impetus to their circulations. Sensational1sm, a characteristic common to all the evening papers, plus cartoons, comics, entertaining essays, and feulliltons also have contributed measurably In their success. Although the evening papers contain the latest news, both national and international, their coverage of the news is brief and concise. Local news, particularly society news, is given great emphasis. Terseness, brevity and liveliness are the characteristics of the writing style in the evening papers.

Tho evening papers are home-delivered. But they

edition) $\frac{\text { lCentral }}{\text { March }} \frac{\text { Daily }}{12} 1957$ Nows (28th anniversary special 
are also sold in the streets by newsboys hawking at passers-by. At the middle and end of every month, all evening papers enjoy greater patronage, because the Liberty Lottery, sponsored by the Bank of Ta1wan, announces its results in the afternoons of these two days. Therefore, all the evening papers issue extra editions on these two days carrying the results of the lottery. These are the heydays for both the lottery winners and the evening papers' circulations. The evening papers are priced at $0.60 \mathrm{NT}$ per copy (equivalent to less than $\$ 0.002 \mathrm{U.S.}$ ), but usually the rate shrinks as the evening gets late.

Tah Hwa Evening News

The founding of the Tah Hwa Evening News in 1950 was a result of the combined efforts of thirteen men. The men, all of them professional journalists, felt that a full-fledged evening newspaper was needed in Talpei, the growing metropolis on the island. Thus, after six months' preparation and planning, the1r paper made 1 ts debut on February 1, 1950, in Taipe1.

The paper started out with a meagor cap1tal. Each of the thirteen men contributed $\$ 1,000$ NT (equivalent to approximately $\$ 66$ U.S. then) which was about the total of his two months' salary. ${ }^{2}$ Typesetting then was consigned

2A Brief Introduction to Tah Hwa Evening News, a mimeographed pamphlet issued by the News, Spring, 1958. 
to a printing firm, but printing was done at the plant of the Central Da1ly News. The news side of the paper-gathering of news, editing, proofreading and other phases of newspaper publishing--was distributed among the thitteen partners who then drew no pay for the1r services.

As business progressed after s1x months of publ1cation, the partners reorganized the paper into a corporation. Meanwile, a sizable capital obtained through loans facilitated the paper's growth in the ensuing years. The year 1956 marked a great change in the paper's ownership and organization. Prosperity enabled the paper to distribute stock to employees and workers who had long, meritorious service records with the paper. Meanwile, employment 1ncreased. At present, there are sixty-nine stockholders, forty-two employees and seventy workers; in addition, there are others who work on commissions, such as advertising sol1c1tors. 3

The year 1956 saw another milestone in the paper's expansion. A new printing plant was erected. The plant, along with a rotary printing press bought in Japan, cost the paper $\$ 2,000,000$ NT (equivalent to more than $\$ 50,000$ U.S.), of which two-thirds was paid from the revenue made from c1rculation and advertising over the past years; the

3Ib1d. 
rest was obtained through a loan from a bank. 4 Prior to April 30, 1956, printing was done by the Central Da11y News. After that date, the paper did its own printing. The present circulation according to a report from the Tah Hwa Evening News, is around 20,000 on weekdays, whereas on Sundays, the c1rculation approximates 25,000 . Sdvertising takes up one-fifth of the total space. Elghttenths of its advertising is from commercial firms, while the rest is from government bulletins. Although the paper is a profitable business, advertising revenue only constitutes 39.5 per cent of the total income with the rest being made up by circulation. 5

Issued seven days a week, the Tah Hwa Evening News is four paged and tablo1d sized. On Sundays, a picture nows sheet is added. Limited space, however, does not restrict the variety of 1 ts contents. The paper, as a matter of fact, contains everything from an editorial, news both national and international, to cartoons, comles, short storles, serials, poems, translations and miscellanoous writings. Varied contents and limised spece do not seem to encourage co-existence. But the Fah Hwa Evening News adopts a style which emphasizes simplicity and con-

4Ib1d.

5 Ib1d. 
ciseness. All news gathered is rewritten by rewrite men to fit into its peculiar style of writing. In its news coverage, local events are given great emphasis. In addition, news of human interest or spicy qualities are played up.

As the paper is a privately owned business, it is 1ndependent in 1ts opinions. However, editorially, it is anti-Communist and an advocate of scientific development, the democratic way of $11 f$ and freedom. Because of its independence, the paper is free from influence or interference from any source. 6

The success of the paper as a tablold-sized evaning news sheet, apart from 1ts varied and lively contents, 1108 perhaps in its management. The high efficiency of its operation has largely resulted from the fact that nearly all members of the paper, employees and workers alike, are stockholders in the paper.7 Thus, the success and fallure of the paper directly affects their interests. This mutual interest is the key to the paper's success in business. At present, the paper is under the directorship of Hsiu-Yeh Keng, a veteran journalist, while Chien Chen, who was a graduate student $(1954-55)$ at the Missouri School of Journalism, is the managing editor.

6Ib1d.

7 Ib1d. 
Tze L1 Evening Post

The Tze L1 (Independence) Evening Post, an evening newspaper founded October 10, 1947, on the occasion of the Chinese National Anniversary, was not an immediate success. In fact, publication was twice suspended because of financial difficulties, and the paper was twice reorganized. But the paper's circulation climbed gradually. The year 1956 sấ the paper augment its facilities by purchasing a rotary press from Japan to Improve 1ts typographical appearance. 8

Despite the fact that all the other evening newspapers are tablo1d sized, Tze L1 Evening Post is the only four-paged, regular-sized paper in the evening fleld. More space enables the paper to use larger type both in contents and in headlines than other newspapers. Local news, particularly society news, is well covered. However, like other evening newspapers on the island, entertaining qualities in the contents are emphasized. In fact, the Evening Post, because of 1 ts space, carries more serials, feuilletons, cortoons and other types of entertalament ban other evening newspapers.

Tze L1 Evening Post with Yu-Chia Lee as the director is a privately owned newspaper. Its editorial attitude

${ }^{8}$ Central Da11y News (28th anniversary special edition), March 12,1957 . 
is characterized by independence and outspokenness.

For example, in discussing China's foreign policy, the Evening Post on December 18, 1955, scomed the abject view that "a wea ckintry has no diplamacy." It said that ing "sthis wrong conception....has done great harm to the national rights and interests since the Manchu Dynasty." Moreover, the paper stoutly maintained that if the author1ties responsible for formulating forelgn policies have this false conception, "they should be regarded as advocates of national suicide and slaughters of national ife." When the Cabinet proposed a revision of the a Publication Law in March, 1958, whereby the government would be allowed to revoke the license of a newspaper if the government-1ssued license was improperly used repeatedly, the Evening Post flatly called the revocation of license "a death sentence" for the newspapers. Quoting the explanation of the Minister of Interior that the revision was designed to protect freedom of the press, the Evenling Post asked, "What does protection mean if the government adds to the Publication Law a new article by which the government is entitled to revoke the license of any newspaper at any moment?"10

9carlton Culmsee, "How Free Is the Press in Free China?" Journalism Quarterly, Fall, 1956, p. 496. ${ }^{10}$ China Post, April 13, 1958. 
$\theta$

Min Tsu Evening News

- The Min Tsu (National) Evening News was originally the second edition of $\underline{M i n}$ Tsu Pao. The latter, a morning da1ly, was later amalgamated with two other failing newspapers to become the present United Daily News. It was not until the end of 1950 that the second edition of the Min Tsu Pao formally emerged into a full-fledged evening newspaper.

The reason the Evening News was not merged with the Min Tsu Pao is that the Evening News was on a better ground financially. In fact, it was sald to be one of the first papers on the 1sland to have used cartoons successfully. The cartoons were attributed among other things to have increased the popularity of the paper. Mention must be made that the cartoons, frequently political in tone, reflect the editorial policy of the paper.

As a tablold-sized evening paper, the Evening News has a good circulation in its field. According to an article entitled "The Press" in the Chung Hwa (China) Year Book, 1957, the Min Tsu Evening News was estimated to have a circulation of $13,000.11$ To make the fullest use of its limited space, the Evening News is one of the few papers on the 1sland that uses the space in between the inner two

${ }^{11}$ Chung Hwa Year Book, 1957 (Ta1pe1: China News Press), p. 70 . 


\section{CHAPTER VI}

\section{NEWS AGENCIES AND INFORMATION SERVICES}

Central News Agency

The Central News Agency, known by its abbreviation CNA, is the Republic of China's largest news service. It was only a s1x-man organization under the Kuomintang Public1ty Board when the agency was founded in 1924 in Canton, capital of Kwangtung Province. This news agency was establ1shed to keep the people duly and accurately informed of the domestic situation as well as the international.

The history of the Central News Agency has been colncidental with the ups and downs of the Republic. In July, 1926, two years after its birth, the agency entered Into a new era in its information service when President Chiang Kal-shek, then the commander-in-chlef of the National Revolutionary Army, led his men in the historic Northern Expedition to do away with the warlords then standing in the way of a unified China. ${ }^{l}$ The expedition necessitated the agency to engage for the first time in organized war reporting and in transmitting government orders.

When the National Government established its new

IBusiness Correspondence of Central News Agency ( 30 th Anniversary special 1ssue), Fall, 1954. 
capital in Nanking in 1927, the agency moved there from Canton and began to emerge as a full-fledged news agency. 2 The Japanese invasion of Manchuria, northeastern part of Chine, in 1931 gave now impotus to 1 to growth. The Kugmintang, realizing that launching a campalgn of words was equally as important as the military resistance, decided to strengthen the agency's organization and charge it further with duties of mass communication.

The appointment of T. T. Hsiao to the directorship brought new life to the agency. The then 38-year-old director, already active among the ranks of revolutionarles, was a dynamic worker from Hunan, Central China. As a young man Hsiao had published at first handbills and then a newspaper for factory workers designed to inspire them to join the revolution. 3 He had come into newspaper work through his belief in the revolution which was aimed at overthrowing the corrupted Chin Dynasty and establishing the new republic. Upon his appointment, Hsiao gave up all his other duties and devoted his time wholeheartedly to transforming the agency into a modern news service. He laid down three basic principles before he took the

\section{IIb1d.}

Interview with I-Wen Hs1ao, son of T. T. Hsiao, May 8, 1958. 
directorship. 4

1. CNA should move out of the Kuomintang party headquarters and through 1 ts own efforts and in co-operation with society and newspapers strive to become a cultural enterpr1se; 2. CNA should cabe empowered to make independent decisions on cholce of news without outside interference and its news should be based on speed and accuracy; and 3. CNA should be permitted to p1ck 1 ts own employees based on merits.

All three principles won unanimous support from the Kuomintang authorities. The change was significant in that it had enabled the agency to enter the field of professional journalism, to gear 1ts work toward serving society and to adopt a free enterprise type management. To bring the above-mentioned principles to fruit1on, Hs1ao planned to set up a radio news network in seven major c1ties--Nanking, Shangha1, Peiplng, Tientsin, Hankow, Hong Kong and S1an; and a ten-year expansion plan. Both plans met party approval, and the radio networks were set up one after another. Th1s had enabled CNA to keep pace with the other news agencies in the world, particularly in radio communication.

The years from 1930 to 1936 saw cont1nuous expansion in CNA. Its personnel alone increasad from twentyfive to 350 and the agency's branch offices from four to twenty-three. Its news antenna penetrated from the costal

4CNA-Past, Present and Future, Ta1pc1, 1954 (Pamphlet In English published by the Central Ners Agency). 
c1ties into the hinterland. Another 1mprovement made during this period was the establishment of news networks in London, Paris, Tokyo, and New York. However, the unprecedented achlevement made within these years was the acquisition of distribution rights of forelgn agencfes' news in China. The agencies were: Reuter News Agency, French Havas News Agency, the Germany Transocean News Agency, the United Press and the International News Serv$1 \cos 5$

The signiflcance of these developments lay not only in the expansion of news sources and the augumentation of 1ts organization, but was regarded more in terms of speeding up the flow of International news exchange.

The elght-year war of resistance against Japanese domination served as a trial to the news agency. The successive victories scored by the Japanese at the beginning of the war forced the National Government to move from Nanking to Hankow in November, 1937, and again to Chungking in October the next year. As the government moved from place to place, the agency followed in 1 ts wake and fulfilled 1ts duties falthfully. For instance, at the start of the war, the Japanese bombed and destroyed the CNA's headquarters and other branch offices in the major

5Ib1d. 
cities. As many as elght CNA staff members were killed in line of duty by enemy bombings. 6

Three features during the war years deserve attention. One was the continuous struggle behind the enemy Iines to maintain underground reporting." In order to report the conditions on the various war fronts, CNA reporters working in the news outposts were the last to evacuate with the rearguards of the national troops. They even worked behind enemy lines. In Peiping, Tientsin and Shanghai, for instance, CNA correspondents and radio operators worked in secrecy after these c1ties were occupied by the Japanese. The Tientsin bureau, for instance, was maintained for as long as five years. Through underground radio stations CNA men kept news flowing to the main office These stations were repeatedly raided by the Japanese secret police and many CNA reporters were arrested or killed. But when one fell, another volunteered to take his place. The Hong Kong and Singapore bureaus were closed only after their occupation by the Japanese. Many of the agency's staffs underwent dangess and risked death to reach Chungking, the wartime capital of China. Others went into hiding for years before breaking through the enemy lines. 7

6Ib1d.

7 Ib1d. 
The second feature was the fast development of war reporting. On the various war fronts, CNA sent out more than twenty teams of war correspondents, each team being equipped with portable radios. Some were warked on the front lines under constant enemy fire. Others penetrated enemy lines and operated with guerillas. On other war fronts, CNA war correspondents were active in General Joseph W. St1lwell's Burma Command, Admiral Louls Mountbatten's Southeast Asia Command, the United States Fourteenth Air Force, Italian Battlefront, Southwest Pacific Theatre, Central Pac1fic Theatre and the European fronts. Norman Soong, a graduate of the School of Journaliam (A.M., 35) University of Missour1, was the first and only Chinese newsman to ride with the superfortresses that bombed Japan and Northeast China. Other CNA war correspondents participated in beachhead landings with the United States Army and Marines in the Pacific. 8

The third feature was the supply of background information of the war to forelgn correspondents. CNA, being the leading news service, dutifully became the main source of Chinese war news for them. The China Fortnightly, a magazine published by CNA, became a valuable source of information about wartime China. 9

8Ib1d.

9Ib1d. 
Adverse conditions of the war did not, however, destroy the spirit of the Central News Agency. On the contrary, not only did it withstand the test, but it grew stronger and stronger as the war progressed. In all elght years of war, the agency never for a day suspended 1 ts supply of news to newspapers at home and abroad. Furthermore, CNA expanded from twenty-three domest1c branch offices to thirty-nine; from four overseas offices to eleven. Its personnel increased from 350 in 1936 to 1,250 in 1945.10

The years 1946 to 1948 saw the expansion of the Central News Agency. The unconditional surrender of Japan In August 15, 1945, opened a promising future for the agency .

In Apr11, 1946, the agency moved from Chungking to reestablish 1ts headquarters in Nanking. Before 1 ts removal the agency had sent veteran correspondents to the Battleship USS Missour1, to Hong Kong, Hano1, Nanking, Talwan, and various strategic points in the mainland to cover the Japanese surrender and to report the grand finale of World War II. Meanwhlle, other CNA reporters were rushed to all major clties to take over the facilities of the news agencies the Japanese had established during the

\section{${ }^{10}$ Ib1d.}


occupation. Thereafter, nineteen domest1c brench offices and elght overseas bureaus were elther reopened or newly established. 11

The Communist revol in 1948 halted the fast growth of the agency. Immediately before the selzure of the China mainland by the Communists, the agency had fiftytwo domestic branch offices, twenty-five forelgn bureaus and 2,654 staff members and employees. 12 On the business s1de, two 1mportant profects were launched. One was the erection of a modern radio station in Nanking. The new communication center comprised fifteen bulldings, housing two powerful 20-k1lowatt units and elght other small transmitters. Through the sky-scraping radio towers, CNA news could reach every corner in the world. The other project was the construction of a seven-story main office. The bullding was to be equipped with all facilities of a modern news agency. Two floors were to be designated for accommodetion of foreign correspondents and visiting Chinese newsmen. 13

While the bullding was still under construction, the Chinese Communists selzed most of the China mainland. In January, 1949, the Central News was again on the road,

\section{$11_{\text {Ib1d. }}$}

12 Ib1d.

13 Ib1d. 
following the government on another exodus.

Mention must be made of the reorganization of the agency into a business enterprise. The agency was placed under control of the government in 1948. It was then planned that 1 ithin a reasonabiy short period the agency "should become the "Associated Press" of China under the joint control of all Chinese newspapers. 14 However, because of the adverse conditions in the face of Communist full-scale revolt, the plan was temporarily shelved, although the principle has never been given up.

In fact, working as a first step toward converting the Central News Agency into the "Associated Press of China," a nino-member supervisory committee, equivalent to the board of directors of a business firm, was formed in October, 1950, after the agency's removal to Talpei.15 The commlttee, composed of newspaper publishers and information officials, was headed by T. T. Hsiao, who had been director of the Central News Agency for elghteen years. In Hsiao's place, Hsu Pal Tseng, former deputy director of Government Information Office, took the directorship.

The past eight jears on Taiwan has brought new iffe to the Central News Agency. Constant 1mprovement in news

14 China Handbook, $1954-55$, p. 191. 15Ib1d. 
coverage, in communicative methods and steady expansion in pusiness have boen exerted. Among the achievements made was the establishment in 1953 of a Western European Bureau, which made possible the extension oflits news network from London to Par1s, Berlin, Bonn and to the very edge of the Iron Curtain.

At present the Central News maintains the following bureaus: 16

Domest1c: Quemoy, Makung, Kaoshiung, Tainan,

Talchung, Hwallen and Keelung.

Fore1gn: New York, San Franc1sco, Washington, Par1s, Berlin, Bonn, Madrid, Singapore, Bankok, Man1la, Tokyo, Seoul, Hong Kong and Macao.

Organizationally, the agency has five departments. They are: editorial, Engl1sh, reporting, communications, and translation and compilation departments. 17

The editorial department, in addition to editing the da1ly Chinese newscasts, devotes sixteen hours every day to keep a continuous flow of domestic and intarnational news to all the local newspapers and broadcasting stations.

16 CNA--Past, Present and Future, 1954.

17Business Correspondence of Central News Agency ( 30 th Anniversary special 1ssue), Fall, 1954. 
The English department is responsible for drafting and sending out English newscasts. Apart from this, it is responsible for training forelgn correspondents. In fact, efghty per cent of Chinese newsmen working abroald were trained by this department. Proficiency in the English language and in typing are the pre-requisites for personnel working in this department. 18

For news gathering, the head office in Taipel depends on the reporting department. However, when major news breaks occur abroad, a moblle force composed both of the reporting and English departments are sent there. These fast-moving forces el ther cover the stories or reinforce the local bureaus.

The work of the communications department is divided into two categories: communications and engineoring. The former is responsible for recelving news reports from the branch offlces, foreign news agencies and for sending newscasts to CNA subscribers. The latter is chiefly responsible for the maintenance, repair, technical planning and improvement of communication techniques. One of the recent 1mprovements in communicative methods was the installation of a Japanese facsimile machine in June, 1952 , replacing the old coding and decoding system. Beginning

\section{Ib1d.}


in November, 1953, the agency had put into use 1ts prev1ously purchased radioprinter machines to recelve United Press news. Through the control center in the agency, news is araed to teletypes installed in the various Taiwan newspapers with which CNA has contacts.19

The Central News Agency, with a past history of thirty-three years, is undoubtedly Free China's oldest and largest news agency. In all these years, it has worked toward serving the public with rellable, first-hand information, and toward promoting international exchange of news. To the Chinese, CNA stands for speed and accuracy in news reporting. A telegram from the Scripps-Howard newspaper chain on the thirtieth anniversary of the Central News in 1954 perhaps may indicate the position of the Central News in its alliance with other world news agenc1es. The telegram, translated in part, reads,

As a supreme news agency in Free China, the Central News Agency has a most important mission-to report to the free world the situation developing daily in these adverse areas.... The future of the free people everywhere relies on a complete understanding among themselves. This understanding can only be made possible through a continuous and free exchange of true information. While extending our good wishes on the thirtieth anniversary of the Central News Agency, we hope this valuable contribution (on the part of the CNA) toward world peace will be continued. 20

19 Ib1d.

20 Ib1d. 
The Pan-Asia Newspaper Alliance

The Pan-Asia Newspaper Alliance was organized in

1949 as an international news-gathering agency operating in Asia. 21 It was started by two alumn of the School of the University of Missour1, Kyatang Woo and Norman Soong. Woo (B.J. 135), former managing editor of China Press, an English-language dally published in Shanghai, and later news editor of Shanghal Shun Pao, was the executive editor while Soong (A.M.'35), former chief of the Tokyo Bureau of the Central News Agency, was the managing editor. Later, Kyatang Woo left the Pan-Asia Newspaper Alliance and $1 \mathrm{~s}$ now editor of the English-language Hong Kong Standard in Hong Kong.

- The 1dea of aestablishing the Pan-Asia Newspaper Alliance occurred to the two classmates after the Communist selzure of the China mainland. They realized that a news agency, Independently organized and operated by Asians reporting objectively the news in Asia, was needed.22 It was then felt that news coverage of Asia, done by forelgn news services, was often prejudiced and slanted to the needs of foreign newspapers, leaving considerable room

\section{China Handbook, 1954-55, p. 191.}

22We1-Tung Ting, "The Development of the Pan-Asia Newspaper Alliance," PQO Hs1u, 1951, p. 147 
for better coverage and more authentic interpretation. 23 As a news agency operated by Asians, the Pan-Asia Newspaper Alliance therefore almed at serving Asian newspapers with good coverag of news happening in Asia.

The physical press conditions in post-war Japan were also instrumental in inspiring the founding of the Alliance. It was first established in Tokyo at a time when the press in occupied Japân, being unable to send nowsmen abroad, was eager to see the establishment of an Asian-operated news organization that would report the news, particularly about the changes on the China mainland, reliably and objectively. The Japanese interest in the changes on the China mainland, caused by the Communist rebellion, had an early beginning. Before the fall of Nanking and Shanghal to the Communists, at least four welltrained Chinese newsmen were employed by some of the major Japanese newspapers to cover the mainland conditions. In view of this situation, the Alliance began its service by providing systematic news reports about the China mainland and other parts of Asia to the Japanese newspapers. The reports, being objective and avolding propaganda elements, had won the confldence of the Japanese press. This greatly facilitated the development of the Alliance.24

\section{Ib1d. \\ 24 Ib1d.}


At the start, the Alliance's operation was limited only to providing correspondence, features and news photographs. Later, as bosiness progressed, it began to furnish regular nêtsoast service in Tokyo, Taipei, Manila and Hong Kong. Moreover, it successfully recruited membership newspapers from countries and territories all over Asia: China, Japan, The Ph1l1ppines, Hong Kong, Malaya, Tha1land, Indonesia, Burma, India and Pakistan. 25

The outbreak of the Korean War brought new impetus to the growth of the Alliance as evidenced in 1 ts increase in nows dispatches. The expansion during this period is accounted for largely by the ablitty and enthusiasm of the two Missouri alumn1. It was sald that their office in Tokyo was then $11 k 0$ that of a military headquarters. A 1/250,000 Korean map was hung on the wall. The map was dotted with little red and blue flags showling the current developments of the war. 26 Both Woo and Soong made frequent trips to the battlefronts in Korea to obtain firsthand information. Woo was a fast writer. Once, after a press conference at alch President Syngman Rhee of the Republic of Korea presided, Woo wrote his report in ten minutes after he and other reporters were taken to their

\section{Ib1d.}

26Kran-Chuen Lu, "Nowsmen in Korean War," Pro Hsiu, 1951, p. 108. 
quarters. He was the first to send his report to Tokyo while other reporters were lined up for their turns to use the telephone booth. 27

The news-gathering technique of the Pan-Asia Newspaper Alliance concentrates only on the most important issues. For instance, when General MacArthur was relleved of his duties in the Far East, the Alliance put all its efforts on this single event. When the armistice talks began in Korea, it switched its focus of attention to Panmunjon, the place where the talks were held. To further illustrate this news-gathering technique, it was Norman Soong who was first on hand to discover and photograph the Communist movement in areas contradictory to the neutral1zation agreement. This had caused General Ridgway, the supreme commander of the United Nations Forces to order that the talks be terminated. The mobile Pan-Asia Newspaper Alliance is always on the go whenever or wherever a major news story breaks. At the signing of the Japanese Treaty in San Francisco in September, 1951, Norman Soong and Kyatang Woo were there. All these examples show that the Pan-Asia Newspaper Alliance displays news initiative and enterprise. 28

27 Ib1d.

28 Peng Yao, "On Comprehensive Reporting," Pao Hs1u, January, 1952, p. 62. 
quarters. He was the first to send his report to Tokyo while other reporters were lined up for their turns to use the telephone booth. 27

The news-gathering technique of the Pan-Asia Newspaper Alliance concentrates only on the most important issues. For instance, when General MacArthur was relleved of his duties in the Far East, the Alliance put all its efforts on this single event. When the armistice talks began in Korea, it switched its focus of attention to Panmunjon, the place where the talks were held. To further illustrate this news-gathering technique, it was Norman Soong who was first on hand to discover and photograph the Communist movement in areas contradictory to the neutral1zation agreement. This had caused General Ridgway, the supreme commander of the United Nations Forces to order that the talks be terminated. The mobile Pan-Asia Newspaper Alliance is always on the go whenever or wherever a major news story breaks. At the signing of the Japanese Treaty in San Francisco in September, 1951, Norman Soong and Kyatang Woo were there. All these examples show that the Pan-Asia Newspaper Alliance displays news initiative and enterprise. 28

27 Ib1d.

28 Peng Yao, "On Comprehensive Reporting," Pao Hs1u, January, 1952, p. 62. 
The outstanding service of the Pan-Asia Newspaper

Alliance during the Korean Wer brought renewed recognition to the organization from the Asian press. PANA, the abbreviation of the organization, has vecome well known to the newspaper readers since the Korean War.

One of the biggest merlts of the Alliance is that it is an entirely private organization. As such, it has no connection with the Chinese government and therefore Its reports are objective and independent except that the Alliance is anti-Commist. The independent stand of the Alliance is the biggest asset of the organization and its reputation as a reliable news source has been built on this. In news-writing, the Alliance is noted for its fresh, lively and vigorous style, artits features are injected with strong human interest. Most of the agency's news file is sent out in the English language.

Thus, today, the Pan-Asla Newspaper Alliance is one of the most outstanding news agencies in Asia. An international news agency, the Alliance serves fifty-six newspapers and eleven periodicals in twelve countries and maintalns news bureaus in the following cities: Seoul, Tokyo, Hong Kong, Singapore, Rangoon, Calcutta, New Delh1, Karachi and Djakarta. 29

29 Ch1ne Handbook, 1954-55, p. 191. 
The China News and Publication Service, Ltd.

The China News and Publication Service, Ltd. is another privately owned news agency. It was founded in June, 1949, by a group of liberal Chinese refugee newspapermen from the mainland, 30 namely, James We1 (the present publisher), Stanway Cheng and others.

The Service, which publishes the mimeographed China News, an English-language daily, distributes both foreign and domestic news. The mimeographed sheet is in actuality the establishment's principal release. The Service is the sole distributor of Reuter news on Talwan. Besides being an agent for the International News Service of America on Talwan, Stanway Cheng, the director of the Service, is a correspondent for this American news agency. 31 with the co-operation of two Chinese dallies, the Service also contracts for the exclusive use of the Associated Press worldwide service in the Talwan area. 32 Because of the personal relations of the Service's publisher and director with the Ministry of Foreign Affairs, the Service is renownea for its authoritativeness in the coverage of

\section{Ib1d.}

31 Ta1wan Directorr, 1955, p. 60.

32Letter from Stanway Cheng, March 8, 1958. 
diplomat1c news.

The China News and Publication Service serves practically all the leading Chlnese-language morning and afternoon newspapers putilished on the figand. More than ten newspapers are buying daily China News international and domestic news services. 33 To cover international news, the Service at present maintains correspondents in Hong Kong, Tokyo, Be1rut and New York.

The China News and Publication Service is still a growing news agency, and it is equipped with radio teleprinters which enable it to supply its clients with news in the original form from all over the world. This service makes 1t possible for the clients to select from among the full and original news copies.

As a modern news agency, the China News and Publication Service also maintains telephone service to a number of special clients for both forelon and commercial spot news. The telephone subscribers are provided with up-tothe-minute t1p-off service day and night. 34

Because of the limfted size of the English-reading public on Talwan, the operation of an English news service is necessarily confined to a small scope. Nevertheless,

33Ib1d.

34 Ib1d. 
the China News and Publication Service, along with other nows enterprises on the lsland, is looking forward to making constant improvements in order to get worldwide news into the 1sland through the fastest channel. Although modern communication facilities are expensive, the importance of such modern means as the radio teleprinters is not overlooked. Stanway Cheng, in reflecting on the need of modern communication facilities by the Chinese press on Talwan, sa1d, "Most of the papers here are served with radio teleprinter service although sometimes they can hardly afford to pay for such modern mass communication service." 35

To provide its readers a general picture of the various aspects of the 1sland, the China News and Publication Service annually publishes a Directory of Taiwan in English. The directory, containing factual and up-todate information beth in words and pactures, fills a need of the English-reading residents as well as tourists, for vital information about Taiwan.

Government Information Office (8)

The Government Information Office is the official spokesman of the administration. Organizationally, it is

\section{Ib1d.}


under the Executive Yuan, the highest administrative organ of the Central Government of the Republic of China. Heading the Office is Dr. Sampson C. Shen (D. Litt, 145, Benares Uniforsity, India), former secretary to President Chiang Kai-shek. 36

The operation of the Government Information Office is divided into three departments. The First Department takes charge of domestic publiclty and lialson work with the Chinese press and issues press releases for the government. It also issues statements for the President and Vice-President of the Republic, the Premier, and the ministers of different ministries. The Second Department 1s responsible for international publicity. It issues publications in English and in several other forelgn Languages for distribution abroad. In addition, it also translates into English important speeches made by government leaders and other reference materials. As part of its duties, the department also provides publicity and reference materials for Chinese missions and consulates abroad. Material-collecting and research are the duties of the Third Department. One of the department's chief functions is to translate materials in foreign languages into Chinese for distribution among the related organi-

$$
\text { 36 Ghing Handbook, 1956-57, p. } 758 \text {. }
$$


zations and government offices for reference use. Apart from these three departments, there is also a Public Relations Section which is responsible for making arrangements for foreign visitors and reporters to visit Free China and rendering free services to resident foreign correspondents. 37

The Government. Information Office holds regular press conferences every Friday and such other press conferences as the occasion may dictate. Usually there are two kinds of conferences. One is given by the chief of a government depertment, who answers questions concerning his own department, while the other is given by the military and forelgn affairs spokesman. There were sixty-four such press conferences held in 1955. Meanwhile, in the same year, 296 forelgn correspondents made use of the various services and facilities provided by the Office. Following is the breakdown of the forelgn correspondents by nationalities: 38

U.S.A.

Britain

Japan

France

Korea

Australia

Philippines
219

29

10

9

9

4

Germany

Denmark

Sw1 tzorland

Vietnam

India

Italy

Sweden

3
2
2
2
7
1
1

37Ib1d., pp. 216-217.

38 Ib1d., p. 217 . 
The Information Office maintains several offices

abroad. The Chinese News Service in New York, for instance, is one of its forelgn operations.

3):

䊁

Other News Agencies and Official Informetion Services

(1) The Office of Information, Ministry of National Defense.

The Office of Information, founded January 1, 1956, is an organization under the Ministry of National Defense. Its primary mission is to provide a free flow of unclassified military information to the public through various news media. 39

As an official military news source, its releases are mainly in the form of combat bulletins, war news or storles and also news pictures. The Office keeps close contact with representatives of all newspapers and news agencies and answers queries on combat information and verifies news reports concerning military affairs. 40 One of its functions as a military information service is to process newsmen's requests for visits to military bases and installations, and to escort them to such visits. In addition, it also arranges the representation of the press at important military ceremonies

39 Ib1d., p. 218.

40 Ib1d. 
and maneuvers and conducts newsmen's tours to the military bases on the offshore 1slands. 41

(2) Te Information Department of the Taiwan Provincial Government

The Information Department was established on August 21, 1947. It da1ly 1ssues press releases, statements, and news pictures for the Governor's Office and various departments, bureaus, and offlces of the Provincial Government. The Information Department is also responsible for handling the registration of newspapers and magazines published on Talwan. Among other offlc1al functions, the Information Department edits and distributes various pamphlets and pictorials to acquaint the people with the developments in the province and the progress of the provincial administration. A movie studio which produces newsreels as well as documentary films for free exhibition is also under the management of this department. 42

\section{(3) The China Union Press}

The China Union Press is a news agency engaged in gathering news from the China mainland and information from behind the enemy lines.43 It is an authoritative
4 Ib1d.
42 Ib1d., p. 219.
43Ib1d., p. 216. 
news agency in these fields. Because its news releases are rellable, forelgn correspondents in Talpel often quote or use the China Union Press' news reports as a source of information for facts about onine meinland. Some of the Hong Kong newspapers are also clients of the China Union Press.44 The press now maintains branch offices both in Hong Kong and Bangkok. The director of the China Union Press is ChI Hsieh.

\section{(4) The Cheng Hsin News Agency}

Besides publishing the Cheng Hsin Hsing Wen Credit Information), the only newspaper on the 1sland that is slanted primarily toward financial news coverage, the Cheng Hsin News Agency specializes in financial, commercial and economic news. 45 It is a privately owned news agency.

44 Yao, op. c1t., p. 64 . 45 Ching Handbook, 1956-57, p. 216. 


\section{CHAPTER VII}

\section{FREEDOM OF PRESS IN CHINA}

A. Constitutional Guarantees of the Press

There have long been controversies as to whether or not the Chinese press on Ta1wan 18 free. Called Free China in contrast with the tyrannical Communist regime on the ma1nland, the Republic of China has a constitution guaranteelng freedom of the press. The Chinese Constitut1on, promulgated on January 1, 1947, has two specific articles dealing with the press rreedom.

Art1cle XI reads: The people shall have the freedoth of speech, academic instructions, writing, and publications.

Art1cle XXIII reads: All the rreedoms and rights enumerated in the preceding Articles may not be restricted by law, except for reasons of preventing infringemint upon the freedoms of other persons, averting an imminent crisis, malntaining social orders, or advancing general welfare.1

After the promulgation of the Constitution, the Leg1slative Yuan undertook to revise the old press 1ar, which has been in force for the previous fifteen years. Long and hot debates continued in the Leglslative Yuan in 1ts successive sessions. It took almost five years to finish the work and a revised press law was eventually

1 Chlng Handbook, 1954-55, p. 187 . 
enacted In Apr11, 1952. The main features of the law remained unchanged. 2

In the first place, it provides a oystem of registration for all publications, 1ncludefg forspors, magazines, and other printed matters. The qualifications of a publisher or an editor are also 118ted. 3

Secondly, it stipulates certain conditions under which a publisher shall be punished: for example, to commit, or to incite others to commit, crimes of treason Insurrection or esplonage; to disturb, or to inc1te others to disturb, the public order; and to commit, or to cause others to commlt, acts of moral turpltude. 4

Thirdly, it provides that in time of war or an emergency, wen the government, as authorized by the Constitution, takes measures to deal with any unforseen crisis, it may ban or limit the publication of certain 1tems, such as military, political, or diplomatic secrets, which tends to endanger public security. 5

B. Press Freedom on Tajwan

The Chinese government on Talwan, endeavoring to

2Ib1d., p. 188 .

3 Ib1d.

4 Ib1d.

5 Ib1d. 
democrat1ze the republ1c, is aware that a free press 1s Indispensable if democracy is to prevall. However, against a background of overlapping crises arising notably from the Japanese aggression up to the recent Communist rebellion, a ripe fulfillment of democrat1c 1deals on the American plan is not cons1dered feasible. In fact, oven at present Free China 18 st1ll at war with the Communist Peiping regime. War makes 1t necessary for a country to restrict Its press because the security of the country hinges to a large degree on the gontrol of information salutary to the enemy. Yet, the Chinese press on Talwan enjoys the amount of freedom as guaranteed by the Constitution and cautions against the 11mitations prescribed in the press 1av.

Test1mony by Ernest Hoberecht, Un1ted Press vice president, who had had 15 years of journal1st1c experience In the Far East, may be of Interest.

I know, he said, that in these countries (The Republic of China and the Republic of Korea) as weil as many other Asian countries there are many people flghting hard to maintain free press.....As far as press reports are concerned, I would say forelgn correspondents in Free China and South Korea haye and are still on joying complete freedom.6

Examples of what has been printed by newspapers on

Garlton Culmser, "How Free Is the Press in Free China," Journal1sm Quarterly, Fall, 1956, p. 493. 
Ta1wan provide more concrete ovidence of offective freedom of expression and Independence of the Chinese press.

The English-language Chine Post is a supporter of the government and of patriotic and ant1-Communist ativi ties, but sometimes 1t volces strong oriticlsm of the government and the Kuomintang.

In the winter of 1955-56, for example, when the national legislature held a series of secret meetings, the Post, In 1ts editorial, stated that such sessions violated

the basic apirit of the law-making body which, constitutionalif, represents the general public....

That some moetings on forelgn policy or military bulld-up should be hold in secrecy is justifiablo. But there are closed meetings on purely domestic 1ssues.... We think that the secrecy of such meetings is far from Justiflablo....

Wo fully agreo wh th law-maker Sa whon he sald that sessions of the Legislative Yuan should be held open unless there are absolutely necessary reasons for secrecy. Let's not forget these qualifying words, absolutely nocessary.7

On April 1, 1956 the China Ners, the mimeographed English-language dally, carried a "Stop Press!" story headlined, "Mao Denounces Stalin as Double-Crosser." It wad made to appear that Polping had broken a wook-long sllence concerning Khrushcher's attack on Stalin. Later that day two Chinese-language nowspapers, Including the

7 Ib1d., p. 494. 
Kuomintang-sponsored Central Daily News, printed translation of the News story. The original story in the Ners was a hoax and, although the Chinese dellght in a joke, some high officials evidently were not amused at being made "April fools." The Talpel correspondent for Agence France Presse, in a tory in the Hong Kong T1ger Standard, an English dally operated by overseas Chlnese, reported:

The ent1re Kuomintang.... was taken in by the rabricated story. Even President Chlang Ka1-shek took a deep interest..... It turned out, according to the report, the publisher who printed the translated version have become involved in hot water with the Presidential Orfice.8

If this was true, the News oditors showed no contrition or añdety at the results of their prank. On Apr11 4 the News carried an editorial ent1tled "Local Elections Slipplng," describing a "lack of enthusiasm among those ellgible to vote for maglstrates and sub-district ch1ers in Talchung and Tainan count1es." The editorial held that dominance of Kuomintang as the best explanation of the racet that fower than 20 per cent of the voters cast "the1r sacred ballots." The editorial went on to say:

There were usually no contenders except the lone candidates backed by the ruling party. Due to maneuvering by party-workers, most of the other rivala el ther dropped out abruptly or were prevalled upon to give up the race....

8Ib1d., p. 495. 
We must chock and counter such passive resistance on the part of the voting public in the local polls. Otherwise, we could not consider local self-government 18 making progress on the 1sland after the Initial success.?

Tho ChInose-language da1lies are equally critical of the government. Among them, Kun Lun Pao $1 \mathrm{~s}$ regarded as one of the more outspoken crit1cs. The paper is privatelyowned and published by a Talwanese, L1 Wan Chu, who recelved his education at the University of Parls in France.10 Like the Chine News, the paper discussed the decline in enthusiasm in loral elections, attributing the apathy to the fact that Kuomintang candidates were usually unopposed. 11

The vernacular United Dally Ners 1s even more outspoken than Kun Lun Pao in criticizing the government. On June 25, 1954, an editorial in the United Da11y News Invelghed agalnst the government's forelgn pollcy by saying:

After the Yalte Conference of 1954, China was placed in an unenviable position. Why did our government conclude a "Treaty of Friendship" with Soviet Russia when we could forecast the Red peril threatening our country? After we had wstablished all unequal treat1es through elght years of antiJapanese war, why should we conclude with Soviet

2

9Ib1d.

10 China Handbook, 1954-55, p. 717.

1lcúlmser, op. c1t., p. 495 . 
Russia such a new treaty impairing our territorial integrity and political independence?.... In the last 20 years, Chinese forelon pollcy has been in a sate of vacillation.12

The Free China Fortinghtly, a Chinese-language magazine gnce edited by the scholarly Hu Sh1h, ambassador to the United States from 1942 to 1945 and former president of the Univereity of Peking, is rated by some as "Exhibit A" among Freo China's free publications.13

Frank and bold, the magazine in an article ent1tled "Leave It to the Judgent of H1story?" criticized Premier 0. K. Yul after he had shrugged off a legislator's Inquiry about government administration and problems of the people's livelihood. The magazine responded differently when the premier sald that only history could pass an objective flugment on the achlevements of government officlals "who had placed the1r entire spiritual and physical energy at the service of the government." "The article in the Free China Fortnightly retorted by saying:

Although we love and support Premier 0.K. Yui, we love our country more. Since Premier Yul's cabinet was formed about 20 months ago,..... what exactly has it accomplished so far?.... 1 s far as Impartial public opinion can judge, among higher offlcials there are not a few who are dawdiling and incompetent and utterly unqualified for their respons1ble jobs. Can Premler Yul close his ejes

12Ib1d.

13 Ib1d., p. 497. 
to the dolngs of these people and leave their

"achlevemente" to the judgment of h1story?14

Tho Contral Dally Nors, a Kuomintang party organ, does not lag bohind when the subject of press freedom is discussed. On Soptomber 1, 1957, the annual Newsmen's Day, the Da1ly Nerre carried an article ont1tled "On Freedom of Press" which sald in part:

Not only we journalists should enjoy the freedom of press and not abuse 1t, but the society and the government should also respect that froedom and not fear 1t. Thus the freedom of press, not abused and foared, will manifest 1 ts function as the foundation of democracy. 15

C. Government Promotion of Freedom of Expression

The examples c1ted in the preceding section will give evidence of the degree of freedom the press has on Ta1wan. However, they show only how dut1fully the press has boen working to maintain such freedom in country where democracy is still in 1 ts infancy. The following examples will show how Important the government concerne publ1c opinion.

On October 15, 1956, President Chlang Ka1-shek called upon the nation to criticize the government and the President himself with respect to six facets of state

\section{Ib1d.} (e)

15Centrel Da11r Ners, Soptember 1, 1957. 
affars: 16

(1) What should be done or undone to convert Ta1wan into a model province where the Three

Peoplo's Principles is carriod out in earnest? 17

(2) How to Increase the effectiveness of the four reformsovements (political, social, economic and oducational) and reduce the ovils of political manlpulation and bureaucratism?

(3) How to onforce wartime austerity and avo1d extravagance in wartime living?

(4) Practicable suggestions on how to rally all ant1-Communist and ant1-aggression forces and bring about a unity of minds among the Chlnese people?

(5) What courses of action should be allowed in the ant1-Comnuniet $s$ truggle and in the offort to secover the China mainland?

(6) Constructive critscisms of the President's private and public 11 and conduct.

The following 1s the summarlzed form of some of the criticloms and suggestions that have appeared in the Taiwan press:

Dr. Hu Shih, former president of the University of

16"Ta1wan Commentary," East and West (a SinoAmerican Cultural and Economic Association publication, publishod each month by Chen En-cheng), Talpe1, Talwan, December, 1956, p. 14 .

17The Three People's Principles, originated by Dr. Sun Yat-sen, founder of the Republic of China, stress nationallsm, people's rights, and people's livelihood. They form the basic political doctrine of the Kuomintang and constitute the highest guiding principles of the Ch1nese government. 
Peking, wrote in both the Centrel Daily Nerrs and the Free China Fortnightly that President Chlang Ka1-shok should depend more on hls subordinates in the government and not to retaln such tight control over the conduct of the government. He also pointed out that the Ch1nese Const1tution does not vest executive authority in the President but in the Executive Yuan. 18

Free Chine Fortnlghtly called upon the President In 1 ts editorial to prepare the nation to govern 1 tself without having to look always to the Presfdent for overy facet of leadership. The oditorial suggested that the President consider three tasks:

One, to prepare the nation to solect candidates to succeed the President by encouraging the omergence of trong opposition parties which will provide the mechanism for choosing the candidates; two, to prov1de for the ostablishment of a responsible cabinet, reaponsible to the people in general rather than to the President personaliy; throe, to nationalize the armed forces by dispoling the loyalty of officers and troops to individuals and transforring that loyalty to the nation as a whole.19

Po1-Ho Tsa1, chalrman of the Ch1nese Red Cross, in Hain Shong Pao (Ner L1fe Journal), adivised the President to limit his activity to commanding the armed forces, to making only top-lovel declelons and to delegating all

18nTa1wan Commentary," East andpest, Ta1po1, December, 1956, p. 14 .

19 Ib1d. 
other matters to his subordinates.20

Tzu-Shul Mpo, professor of National Ta1wan Un1versity, cited in Free China Fortnlghtly that freedom, democracy and obedience to graw are the modern trinity and attributed the 1088 of the malnland to fallure of the government to observe this trinity. Mao stated that the government must set the example for the people by strictly adhering to the letter of the $1 \mathrm{aw} .21$

Ch1-T1en Chen, a Youth China Party leader pointed out in the United Da1lr Ners; that the raling party had not permitted the minority parties to ongage in peacerul activ1t1es before and during the Sino-Japanese War and that the two minority part1es (the other belng the Democratic Soc1al1st Party) had not onjoyed a normal development. He suggested that the ruling party could fac1litate the growth of the minor parties by four courses of action:

One, by protecting the freedom of expression; two, by giving holp to private newspapers; three, by encouraging opposition candidates in ail local olections; four, by encouraging the members of the Control and Legleletive Yuans to Preely express their opintons.22

The Kuomintang-sponsored Central Da11y News was

20 Ib1d.

$21_{\text {Ib1d.., p. } 15 .}$

22 Ib1d. 
also involved in the rally. It carried an article by Chlang Yun-tien, a loader of the Democratic-Sociallst Party, which doalt wh converting Talwan into a model province under the Three People's Principles. Chlang commented that the principles of nationalism should differ from that of Naz11sm and Fascism by being non-exclusive. Reforring to democracy, ho advised the Kuomintang to abandon 1ts paternalistic control of the nation and to allow the people to rule themselves. Chlang held that in order to roalize the Throe People's Princlples on Talwan the Kuomintang would have to abandon 1 ts special position and carry out these reforms: respect the people's rights and personal freodom, refrain from using government achlnery to further 1 ts partisan program, freo all milltary and securlty personnel from party allenment. 23

Meng-Wu Sa, doan of the National Talwan University Law School, blamed bureaucratism for most of the polltical trouble of the government. It is the system, he pointed out, that makes the officials 1rresponsible and which must first be reformed so as to facllitato polltical abievements. To solve the problem of bureaucratism, Sa offered two polnts: one, assign one job to one agency to avold overlapping and dupllcating functions; two, clearly define

\section{Ib1d.}


jurisdiction of agenc1es. 24

Fu-Kuan Hsu, profosscer at Tunghal Un1versity, elected to discuss the sixth point on which the President desired crit1c1sm--crit1c1sm of the President's personal conduct. Hou's article, printed in the Free Chine Fortnightly, was oummar1zed In the East and West, an 1ndependont English-language monthly.

Hisu noted that the Prosident's strong will, backed by moral strength, has developed stubbornees whlch [S1e] Often serves the nation poorly. Hsu asserted that the President's advisors and assistants have served him badly by carofully screonlng all information that comes to his attontion so as to avold upsotting the President. Th1s has only corved to widen the discrepancy between the President's viow of things and the roality of things Ho ala crit1cized the Prosident's Inability to take honest advice. Ho also found rault with the members of the government who use the President's name to accuse opposition elements of opposing the President and thereby beconing traltors to the party. 25

The bold and stralghtforward attitude of the Chinese press in their eritiolsm of the administration and the Prosident rurther suggests the extent of froedom the press on joys on Ta1wan. There 1s no press censorsh1p of any kind before newapapor 1s printed. But all printed matters are checked by the secur1 ty offlcors after their publication. 26 As war 1s st1ll on, "one might expect

24 Ib1d., pp. 15-16.

25 Ib1d., p. 17.

26 Ch1ne Hardbook, $1954-55$, p. 188. 
restrictions on the release of information of military value, and certainly there is the type of censorship at the source in Ta1wan."27 The editors are held responsible 2. for the printed words. There are no statutes Iimiting press freedom as to what to play up and what no to, but In the face of Communist aggression the newspapers are not expected to print materials that would give ald and comfort to the enemy. As public informants and carriers of 1 deas and oplnions, the newspapers are expected to raise moralo, roster an ant1-Communist 1 deolog and onl1ghton the public. The Kuomintang is often criticized as sponsors of party press. In fact, some of the largest-c1rculation newapapers on Talwan are party-operated and there 18 one, the Hsin Sheng Pao which is sponsored by the Talwan Provincial Government. Yet their roles are not merely official organs of the party, they serve, with their diverse oplnions on various subjects, to enlighten the publ1c.

Carlton Culmser, dean of humanities and sciences as well as head of journallsm department of Utah State College, wrote in the Journal1sm Quarterly (Summer, 1956) after a year's stay on Talwan:

Among the publishers and executives of some of these privately operated newspapers are Kuomintang party members. But it is unwiso to assume that the

27 Culmser, 오. c1t., p. 499. 
party has in all ways a monolithic character. On the broad aim of reuniting China it is safe to say that virtually all aro agreod, but on certain other issues and on means and methods there 18 considerable disagreement.... 28

Concluding his artiele entitled "How Free Is the

Press in Free China," Professor Culmsee said:

The Chinese Constitution gives them [the journalists] a basis on which they can bulld. Within and without the Kuomintang there are genuinely liberal elements, working toward freedom. These are elements we can not 1 gmore.29

The Chinese Publication Law which was officially made publ1c on December 16, 1930, has been revised many times. But the main features and the spirit of the law have remalned virtually unchanged. The last reviged version was onacted in April, 1952, after almost rivo years of debates and discussion in the Legislative Yuan, the law-making body in the Chinese government.

$$
\text { Recently, however, a proposed revision of the }
$$

Publication Law, drafted by the Ministry of Interior, was Introduced to the Leg1slative Yuan for passage by the Cablnet on March 28, 1958. The proposed b111 revised olfhtees of the forty-five articles while two more articles were added. The most important points in the bll were summarlzed in the April 13 1s sue of the English-language

$$
\begin{aligned}
& 28 \text { Ib1d., p. } 500 . \\
& 29 \text { Ib1d., p. } 501 .
\end{aligned}
$$


China Post as follows:

If a newspaper publishes anything wich the government thinks should not have been published, that nowspaper may bo given a warning; three successive warnings will make the paper liable to Gxpension of publication for a certain period of tilio, and three successive suspensions w11. automatically be followed by cancellation of 1 ts registration.

This has touched off a wide-spread indignation among the Chinese newspapers and pressmen. However, according to Chlung Chin Tion, Minister of Interior, the government has no intention to restrict freedom of the press. In a statement issued through the Central News Agency, he urged the press not to misunderstand the main purpose of the proposed revision of the Publication Law which was designed "to prevent yellow journals from flooding the market." He explained that the revision "does not grant city and Holen (equivalent to United States county) government the right to close down anj newspaper or magazine." They cannot close down anj publication unless it 1s approved by the Ministry of Interior, he added. On the contrary, he sald, the proposed revision $1 \mathrm{~s}$ meant to protect freedom of the press by limiting the ride circulation of Improper publications. Commenting on the revised article which grants the government the right to revoke the registration card of any publication, Tien sald that from the legal point of vier, the govermment is entitled to revoke the registration card which it has granted to a publisher 
If that card has boen usod improperly or 111 ogally. 30

The Chinese press, particularly the private newspapers, on the other hand, bltterly accused the government of dopriving press of freodom. 31

In an oditorial ont1tied "Wo Protest with Grier," the Influential United Dailr Ners sald that "Any law which grants the government the right to close down newspaper is unconstitutional, and hence can never bo found in any domocrat1c country." 32

The indopendent Kung Lun Pro in an oditorial oplnod that "If nowspapors which are alroady in distress have to worry about possible cancellation of thelr 11cense, they wll be able to do nothing but keep silent." 33

The Chine Post in an oditorial ont1tled "In Dofonse of Freedom of Press," declared on April 13:

The passage of the proposed b1ll.... would place In the hands of the government a dangerous woapon whlch could bo used by undomocratic, narrow-minded unscrupulous officials for throttling all publlcations, good or bad. Thore are many officials in the present government about mose sincerity wo do not have the slightest doubt-ospecielly those who were also pressmon not so many years ago and who therefore are well acqualntod with tho eifficultios confronting those engaged in the journal1st1c profession. But there are alse officials who cannot be trusted....

${ }^{30}$ Ghine Post, Apr11 12, 1958.

31 Ib1d., Apr11 13, 1958.

32Ib1d., Apr11 14, 1958.

33I Ib1d. 
...The requirement that a newspaper or magazine must be registered with the government before it can bo publishod 1s in 1 toolf an infringement of this rreedom.

...We wish to express the following hopes: (1) We hope that 8970 rnment will real1ze the noedlessness of the propiged revision of the Publication Law arf voluntarily withdraw the bill it has submitted to the Leglolat1ve Yuan. (2) Ho hope the farsighted members of the Legislative Yuan will refuse to pass the bill if the government falls to withdraw 1 t. (3) We hope the public, Including our readers, w11 omploy all means ly ing within their power to support the struggle of Chinese pressmen against the placing of rurther restrictions on froedom of the press in this country.

To counteract the proposed revision of the Publ1cation Law, the Ta1pe1 Newspaper Association met on April 12 in an attempt to prevent the passing of the b13.1. In addition, efforts were being exerted to urge the Cabinet to withdraw the b11l. A resolution was reached at the meeting to:

(1) Appoint a delegation to present the views of the newspapers on the b1ll to Premier $0 . K$. Yul and V1ce Premier Shao Ku Huang. (2) Appoint a special group to study the detalls of the b111 and make comments thereon on behalf of the nerspapers. (3) Hold a tea reception next Tuesday to exchange views on the bill with logislators elected by press circles and those who have worked in the newspaper business. (4) Issue a doclaration and draft a letter to the Legislative Yuan to denounce the b111. 34

The passage of the bill is up to the decision of the Legislative Yuan, the top law-making body in the Republ1c of China. The leglslators, according to a China

34Ib1d., Apr11 13, 1958. 
Post report on April 13,assured local pressmen that the Leglslative Yuan would handle the proposed revision of the Publication Law with great care and give it a "fair and reaschabio consideration to ascertain whether it 18 contradictory to the apirit of the Corstitution of the Republic of China."

On April 14, the Post carried a front page report in which it viewed optimistically the favorable support from the legislators:

The consensus of opinion of the three conveners of the committees on Home Affalrs, Education, and C1vil Criminal and Commercial Laws of the Leg1slative Yuan, which have been charged with the task of examining the draft bill for revising the Publication Law, is that the Legislative Yuan will meticulously handle the drart bill in favor of freedom of the press.

The case is still developing at present. Thus, the results are not known. But from the information gathered, the efforts made by the Chinese newsmen seem to have already dram favorable support and sympathy from the Legislative Yuan which will make the ultimate decision. The offorts of newsmen in counteracting the adoption of the proposed Publication Law prove that whenever frefdom of the press is in question in Chine, there are always men who will flght desperately to prevent 1 ts infringement. 


\section{CHAPTER VIII}

\section{ADVERTISING}

Advertising and circulation constituti the princ1pal revenue of newspapers on Talwan. Generally, $35.4 \%$ of the total space in the dall1es currently published on the 1sland is given over to advertising. The ratio between circulation and advertising varies greatly from paper to paper. Although there has been no accurate data ava1lable about newspaper advertising, one source indicates that the revenue derived from advertising constitutes 45 to $55 \%$ of the total income in such leading newspapers as the Central Daily News, Hsin Sheng Peo, China Da11r Ners and the United Da1lr News.' However, in the case of smaller newspapers, the situation is not so prosperous.

As advertising occuples such a high percentage of space and contributes importantly in finance, most of the Chinese newspapers today rely on advertising revenue for existence. An article entitled "The Trend of Newspaper Advertising" published in the October, 1953, 1ssue of Pao Hs1u, a magazine devoted to the study of journal1sm, had this to say with regard to the dependence of Chinese newspapers on advertising for existence:

10a Chen, "Ta1pe1 Newspaper Advertising," Pao Hsiu, December, 1957, pp. 96-97. 
If there 18 no advertising in a newspaper, the thirty to fifty per cent of the apace thus vacated w1ll have to be r11led up by the oditorial department. This, although foasible, will be very costly to the newspaper. However, if there $1 \mathrm{~s}$ no advert1sing revenue, the effect will be so serlous that no newspaper 13. capeble of oolving the problem. The existence of a paper wil bo threatened if advertising revenue is cut off.?

Advertising not only makes up a major income for most of the Chinese newapapers, but it also contributes in roducing the price of nowspaper. According to an est1mate revealed in the art1cle "The Trond of Newapaper Advertising," the production costs of a copy of newspaper generally exceeds 1 ts unit price by fifty per cent or more. Th1s 1llustrates that were it not for the revenue of advertising, the unit price of a Chinese newspaper would have been fifty per cent higher. Since the present price of all the morning papers on Talwan 18 0.80Nr loquivalent to $\$ 0.022$ U.S.) without advertising revenue the price would have to be $1.20 \mathrm{NT}$ (equivalent approximately $\$ 0.04$ U.S.)

Nearly all the Chinese newspapers on Talwan carry advertisements at the botton of the front page, usually occupying one-fourth of whole space. The colum space Immediately underneath the nameplate 1s also sold for advertising at a higher rate because of 1 ts prominent

2Chlen-Chu Pe1, "The Trend of Newspaper Advert181ng," Pao Hs1u, October, 1953, p. 65 . 
position. As a rule, bigh rate 1s charged for advertisements on the front page. Advertising on the rront page usually contains matrimonial announcemonts, department store sales and medicine advertisements. All the rest of the pages except the local news page and the supplemertiary page carry advert1sementa.

Because of newaprint shortage, extravagant use of

the limited space for advertising purpose is unjustifiable. Therefore, Instances where a full page 18 devoted to a single advertisement as in many American newspapers is rare, and even a half page is seen only occasionally. Instead, most of the advert1sements are modest in s1ze with 11ttle display qualities. Oa Feng Chang, advertising manager of the China Daily Ners, sald in an articlo "The Cris1s of Freo China's Newspaper Advertising" which appears In the March, 1953, 1s8ue of the Pao Hs1u:

If a newspaper wants to carry more and better advertisements, it should pay attention to the qualities of its advertisements, that 1s, advertisements should be small rather than large.... Higher rates should be charged on large advert1sements. To do this, not only will it reduce the waste of space, but it will also help to boost the prestige of a newspaper; and at the same time, it will not affect the advertising revenue.3"

The bulk of advertising in Chinese newspapers comes from commercial firms, governmental bulletins,

30a Feng Chang, "The Crisis of Free China's Newspaper Advertising," Pao Hsiu, March, 1953, p. 105. 


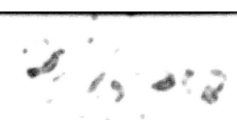

bidding announcements and legal notices. Commercial advert1sing is largely from movie houses, pharmacies, department stores and restaurants. Advertisements of super markets, frequently seen In Ameriean nowpers, are never seen In Chlnese newapapers. Al though Ta1wan has no Amer1can-style super markets, vegetables, meats and rice are seldom seen advertised in the vernacular newspapers. Government bulletins, mostly from the provinclal and munlc1pal governments, are usually administrat1ve orders or regulations that concern the publ1c. The munic1pal government of Ta1pe1, for Instance, periodicaliy announces the deadilne of tax payments through newspaper advertising. Matrimonial announcements, advertisements rather than society news 1 tems as in the case of American newapapers, takes up considerable amount of the advertising apace, particularly on hol1days. The soc1ety page in any Chinese newspaper rarely carries wedding news with the exception of that of people whose names make news. Red, considered a lucky color by the Chinese, is extensively used in these announcements. The space Immediately undernes th the nameplate is a preferred position for this purpose. Mov1e advert1sements are the only ones that use 11lustrations frequently. In some of the newrepers l1ke the United De1ly News, en ent1re page 1s given over to mov1e advertisements. Large, display type faces are used 
to attract attention in these advert1sements. American movies, onfoying a mounting popularity on the 1sland, are usually advertised with both the English t1tles and their Chinese translations. Portralts of the movie gtars are also printed. Compared with other advertisements, movie advertisements are more artistically designed.

Classified advertising is underdeveloped in most of the Chinese newspapers, which commonly carry only twenty or less of the short advert1sements. The only newspaper that has many classifled advertisements is the Central Da1ly News. Although 1t would be Inadvisable to jump to the conclusion that the reason for this is that the Central Da11y News 1 s the best newspaper on the 1sland, undoubtedly 1t does indicate the prestige the Central Da1ly Ners enfoys. The categories under the classifled advertising fall generally 1nto: legal not1ces, real estate for sale, houses or rooms for rent, sales, personals, lost and found and job opportunit1es. However, it is the real estate that composes a blg percentage of the classifled advertisements in most newspapers. Th1s is especielly true on weekends when prospective bujers have time to make visits. Black bold-face type is used in classified advertisements to arrest the attention of the readers. Color, usually red, is extensively used in advert1sing. The over-use of the red color tends to ruin the 
Integrity of the paper's typographical appearance. As Chinese is read from top to bottom and from right to left, most of the advertisements are la1d out in the form of parallel columns.

Commerce and Industry are not hlghly developed on Ta1wan. The reciprocal effects of advertising to stimulate the growth of commerce and Industry have not jet been made convincing to the Chinese merchants. A survey made in 1953 showed that more than fifty per cent of Talwanese merchants engaging in native production had not developed the habit or advertising their merchandise.4 To remedy this situat1on, newspapers customar1ly omploy advertising solicitors to expand advertising patronage. The solic1tors are not on the pay roll of the newrepaper and the1r 1ncome depends on the commission they recelve from their soliciting efforts. 5 Although the use of these solleltors has brought Immediate results to newspapers, their ungulded onthusiasm has done great harm to the papers too. An article on the crisis of Free China's newspaper advertising had this to say with regard to the qualities of these solicitors:

The advertising solic1tors have not developed the hablt of searching for advertising clues from the news. Nor, have they done anything to pursue

4Ib1d.

5Ib1d. 
those merchants wo do not have the hab1t of advertising their merchandise. Ifistead, often 1t 18 the case that when the solle1tors of var1ous newspapers spot an advert1sement in one paper, they would all go to see the advertiser to solicit patronage in the papers they represent. Th1s has brought extreme uneasiness and anxiety to the patrons. As a consequence, the merchants would simply refuse to advertise in any newspaper. Even when the merchants foel it 18 necessary to advert1se, they would place a modest advert1sement once or twice in a more a greeable newspaper so as not to st1r the attention of other solic1 tors. 6

In order to attract more advertising, it has become a general practice for Chinese newspapers to give discounts to their patrons. However, the discounts are given at random without adhering to proper princ1ples. The discount system has been adopted to sat1sfy the psychology of the advertisers. But as there is no adequate standard regardIng the amount of discount to be given to a certain patron, the patrons can hardly be satisfied. Instead, they demand further discounts. Oa Feng Chang, advert1sing manager of the China Da1ly News, wrote in the March, 1953, 1ssue of the Pao Hs1u:

Personally, I advocate the discount system. But in 1 ts handling, we should use 1 t as a means to adjust the advertisements of different natures. Because the functions of a newspaper 110 in spreading news, and leading socloty toward progress, any Information salutary to the public must not bo omitted. Information selutary to the public may be printed without any charge, whereas information

\section{Ib1d.}


userul only to a few should be charged.... The retalning of the discount system will be helpful in bringing steady revenue to the papers. Unfortunately, some of the newspapers give discounts Indiscriminatelj to all the patrons, and the rate of discount is frequently 1rregular. Furthermore, in the midst of keen competition, it has been the practice that when one newspaper gives a twenty per cent discount, its rival would make 1t a thirty per cent discount. Th1s has cast great confusion on the patrons and encouraged them to make further bargaining for lower rate. 7

The news value of the advertising not only has often been neglected by the merchants, but even by the newspapers themselves. However, the advertisements in the Chinese newspapers contain a high potency of news value. For Instance, b1dding announcements are 1mportant news to the prospect1ve merchants and contractors. College and university entrance examination not1ces to the 1sland's thousands of middle school graduates each summer 1s 1mportant news. In addition, such other announcements as movies, commercials, government bulletins, matrimonial announcements, funeral not1ces, legal not1ces all contain news value. However, the co-ordination between news and advertising 18 not well handled. In his article "The Cris1s of Free China's Newspaper Advertising," Mr. Chang said in part:

Speaking of co-ordination, it is essential that the attitudes of the news and the advertisement

$$
\text { 7. }
$$


userul only to a few should be charged.... The retalning of the discount system will be helpful in bringing steady revenue to the papers. Unfortunately, some of the newspapers give discounts Indiscriminatelj to all the patrons, and the rate of discount is frequently 1rregular. Furthermore, in the midst of keen competition, it has been the practice that when one newspaper gives a twenty per cent discount, its rival would make 1t a thirty per cent discount. Th1s has cast great confusion on the patrons and encouraged them to make further bargaining for lower rate. 7

The news value of the advertising not only has often been neglected by the merchants, but even by the newspapers themselves. However, the advertisements in the Chinese newspapers contain a high potency of news value. For Instance, b1dding announcements are 1mportant news to the prospect1ve merchants and contractors. College and university entrance examination not1ces to the 1sland's thousands of middle school graduates each summer 1s 1mportant news. In addition, such other announcements as movies, commercials, government bulletins, matrimonial announcements, funeral not1ces, legal not1ces all contain news value. However, the co-ordination between news and advertising 18 not well handled. In his article "The Cris1s of Free China's Newspaper Advertising," Mr. Chang said in part:

Speaking of co-ordination, it is essential that the attitudes of the news and the advertisement

$$
\text { 7. }
$$


should be consistent..... I once read an advertisement In a paper introducing some well-known physician. But, in the same 1 ssue an article on the supplementary page says that the physician 1s a quack. Th1s certainly would have confused the readers.8

Discussing the technique of arranging the advertisements, Mr. Chang had this to say:

In editing and arranging the advertisements, the oditor has to take the nature of the advertisements into consideration. In certain cases, advertisoments of the same nature should be put together, whereas in other instances, the arrangement should be quite the opposite. For instance, two perfume manufacturers may advertise in the same paper and on the same day. It may also happen that both their copy stresses that their perfumes are the most fragrant, of the bost quality and also the cheapest. If both advertisements should be put s1de by s1de, not only nelther of the manufacturers would be sat1sfied, but the readers would also be confused deciding which brand is better. On the contrary, if two department stores give sales, then $1 \mathrm{t}$ is justifiable that their advert1sements be put together so that the store omers may enter into real competition and also that the roaders may benefit by a fair comparison.9

\section{Advertising copy in Chinese newspapers leaves}

great room for 1mprovement. Information about the advert1sed 1tems is either Insufficient or not spec1fic enough to attract customers. In pointing out the defects of Chinese newspaper advertising and the new role of advert1sing, the article ent1tled "The Trend of Newspaper Advertising" sa1d in part:

\section{Ib1d.}

9Ib1d., p. 105. 
In addition to helping with the sale of merchandise, today an advertisement should be equipped to transmit economical knowledge as well as information about the merchandise. This 1llustrates that advertising has changed from 1 ts former position as a subordinate to production f1rms to an independent medlum between production and consumption.

Henceforth, advertising should be directed at the needs and wants of the consumers. A scientific analysis as to the economical value, direction for use and the components of an advertised 1 tem should be made availabie in the advertisement so that readers may be sufficiently convinced and aroused to purchase the 1 tem. It is only natural that consumers lacking an adequate knowledge of a merchandise will not avall themselves of an interest to buy it no metter how good the merchandise may be.

Some of the advertisements, especially those for medicine, have no elaborate explanation other than the name of the manufacturer and a fer slogans. This 1s contrary to sclentific methods. To the advertisers, this will not bring about the results as ant1c1pated. Besides, it is a waste of money. On the part of the newspaper that carries the advertisement, 1 may be interpreted as being lukewarm in 1 ts service to the pubile. Therefore, in the case of medicine advertising, the advertisement should at least give an explanation as to the contents of the medicine, 1 ts functions and the directions for use. Stereotyped slogans alone cannot arouse the interest of the prospective buyers.10

Limlted space, negligence by the merchants, and a lack of artist1e taste in layout are the greatest weaknesses in Chinese newspaper advertising. The fact that advert1sing occup1es more than thirty-five per cent of the space in most Chinese newspapers, and the fact that the very existence of the Chinese newspapers depends on ad-

10Ib1d., pp. 66-67. 
vertising revenue indicates that improvement in advertising technique can be anticipated. 


\section{CHAPTER IX \\ CIRCULATION}

Compared with American nerspapers, c1rculation is more Important to Chinese newrpapers in the matter of income. It is not upon advertising but primarily upon c1rculation that the prestige of a Chinese newspaper depends.l Although advertising revenue has gradually const1tuted an Important Income to Chinese newspapers, it is upon the foundation of circulation that the advertising Fevenue is built.

The ract that commerce and industry are not highly developed on Taiwan and the fact that Chinese merchants have yet to be convinced of the effects of advertising further reveal that Chinese newspapers emphasize c1rculation for extstence. A newspaper with a good c1rculation status is in a favorable position to solicit advertising. Advertialng revenue has been on the increase in large newspapers 11ke the Central Da1ly Ners and Hsin Sheng Peo whose advertising revenue have attalned forty-five per cont of the total income wh the remainder being made up from circulation; this phenomenon, however, 1s limited only to these and a fow other exceptional cases with which other

1Chu-Hsin Chen, "C1rculation and Advert1sing Which 18 More Importanti" Pao Hs1u, December, 1956, p. 86. 
newspapers cannot compete very well.2

Circulation figures of Chinese newspapers are kept as confidential informatioh. In the face of keen competition, it is natural that such information, if revealed, might affect the advertising prospects of those newspapers that have low circulations. There is no such organization as the Audit Bureau of Circulation on Taiwan; therefore, accurate circulation figures cannot be made available from an official source. However, according to Pin Yan Hao, formes director of the southern edition of the China Daily News and member of the board of directors of the National Newspaper Association of China, the circulation figures are roughly estimated as in the following table. The National Nerspaper Association of China was one time in charge of distributing newsprint to all the Chinese newspapers; the distribution was based on the claimed circulations as well as the investigation of the association. The figures below, though by no means exact, are correct to the best knowledge of Mr. Hao. While the table is far from being complete in 1 ts coverage, it perhaps may serve to outline the general circulation picture of the Chinese press on Taiwan:

Central Da1ly News, Ta1pe1

Taiwan Hsin Sheng Pao, Talpei

Ta1man Hsin Sheng Pao, Kaohsiung

65,000

38,000

17,000

2 Ib1d. 
Chine Da1ly Ners (northern edition) 15,000

China Da11T NeIs (southern edition)

25,000

United Dalis Vers. Talpel

crodit Information, Talpol

Kung Lun Pao, Tralpei

Tah HVa Evening Nerg, Ta1pe1

IIn Isu Evening News, Talpel

ChIna Post, Tripe1

China Nows, Talpe1

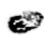

50,000

22,000

5,500

37,000

13,000

5,5004

There are thirty-two newspapers including two English tal dally clrculation of all these newspapers is approximately 336,706 according to an estimate made in Pao Hsiu, an authoritative magazine devoted to the study of journaliam. 5 This suggests that about one out of every thirty-four people on the 1sland reads a da1ly paper. It must not be overlooked, however, that each copy of a Chinese newspaper circulates widely. Although many Chinese cannot read or speak mandarin, all members of educated families usually read each newspaper to which the family subscribes. Too, 1t should be remembered that the average family consists of about six persons. It is also a general practice of Chinese offices, both official and private, to subscribe to several newspapers for their emplojees. In addition, newspapers are posted in such places as the park and city

3Interview with Helen Yu, former reporter, Chine Post, December 26, 1957.

4Memorandum dated December 1, 1957, from Stanway Cheng, director and editor of China News.

50a Chen, "Talpel Nawspaper Advertising," Pao Hsiu, December, 1957, p. 102. 
hall where a large number of people may read them.

W1th regard to the classifications of readers of the Chinese newspaper, there is no data available other than that from the Central Daily News. The Central Daily News made an analysis of the occupations of its readers in 1953 and the results were tabulated as follows: 6

$\begin{array}{ll}\text { Military } & 16 \% \\ \text { Political } & 14.5 \% \\ \text { Educational } & 13 \% \\ \text { Cultural } & 12 \% \\ \text { Police } & 10 \% \\ \text { Business } & 9.5 \% \\ \text { Students } & 8 \% \\ \text { Transportation } & 6 \% \\ \text { Industrial } & 4 \% \\ \text { Agricultural } & 4 \% \\ \text { Others } & 2.5 \%\end{array}$

The above table indicates that the military comprises the highest percentage of the Central Daily News' reading public, while industrial and agricultural workers constitute the lowest. The fact that business occupies only nine and one half per cent suggests that Chinese merchants have yet to be convinced of the effects of newspapers, particularly in relation to advertising. If the above table can be thought of as representative of the general situation on other newspapers, it may be said that the table serves to point out the directions to which circulation efforts should be exerted.

6 The Annual Report of the Central Daily News, 1950 through 1956. 
All the six-paged newspapers on Taiwan are sold at $\$ 0.80 \mathrm{~N} . \mathrm{T}$. (approximately $\$ .022 \mathrm{U.S.}$ ) per copy or $\$ 24$ N.T. (approximately $\$ .66^{2}$ U.S.) per month for subscription. The dallies, all published seven days a week, are home-delivered to their subscribers by Gicycle-riding carriers. Morning newspapers are mostly delivered before 8 A.M. each day. But they can also be bought from magazine stands or by street sales. The evening newspapers are also home-dellvered. Apart from thet, they are sold through hawking by newsboys in public places like railway or bus stations, restaurants or on the street. For out-oftown delivery, the morning newspapers are shipped by rail, truck or afr. Most of the large newspapers have their own trucks standing by for out-of-town delivery in the event there is a delay in press time or the schedules of public transportation systems are missed. The Central Daily News is the only newspaper on the island that has its own airplane for delivering its newspapers to readers in the southern part of the island. 7 Customarily, subscription fees, charged usually by the month, are paid at the end of the month rather than the beginning. Large newspapers like the Central Daily News and Hsin Sheng Pao maintain in various towns circulation agencies which are responsible

7 Central Daily News, March 12, 1957 
for soliciting and delivering papers to readers in their respective areas. These agents are not on the regular payroll of the newspapers, but are paid commissions according to their efforts in soliciting subscriptions.

Chinese newspapers generally use both the little merchant plan and regular employee basis in their carrier system. The former plan is mostly used for street sales. Newsboys, under this plan, derive a profit by buying the papers at a discount and selling them at the regular price. Under the employee plan, carriers are assigned different routes to deliver papers to subscribers and are paid on a monthly salary basis. Carriers working on the latter plan are mostly college students who can cover their routes in about two hours each morning and can be ready for class attendance at eight o'clock. 8

The variance in circulation flgures among the Chinese newspapers is worthy of study. There is some question why, under the present clrcumstances when all major morning newspapers are restricted to six pages and the news sources and prices are practically the same, there should be such difference in circulation figures. This difference is usually attributed to the variance in typoappearance and in content. Mr. Hen Dien Lo, in an article

8Interview with Ho Chin Peng, former editor-inchief and c1ty editor of the Central Daily News, April 2, 1958. 
entitled "The Cause and Effect of Circulation," published In the March, 1953, 18sue of the Pao Hsiu (similar to the Journallsm Quarterly), had this to say:

The veriances in circulation status among the Chifor newspapers should be attributed fundementally to the varled typographical appearance and contents of a nowspaper. The readers' oyes are sharp. Typograph1cal appearance has a great significance on circulation. Speaking of contents, it is only natural that the readers all stop raading a newspaper whose contents are not to his interest. There is no definite standard so far as typographical appearance are concerned. It is entirely up to the cholce of the readers.

But contents are most essential in relation to a paper's clrculation. They are the crystallization of reporters' brain and $l e g$ work. If they report accuately without missing the day's important events and if their paper has every thing that others have and at the same time contalns some special news solely which others do not have or much inferior in their coverage, not only will this show that the reporters of this paper are superior to others, but it will also attract more circulation to the paper.?

The question as to whether there remains any room for circulation expansion in view of the present total circulation of all the newspapers on the 1siend is dubatable. Observations made by the Chinese press in general hold that there can be no measurable increase in circulation. Horover, In comparison with the newspaper circulation status during the Japanese occupation, considerable room remains for improvement. There are more newspapers now on the 1sland than there were during the Japanese occupation. Then

9Jen-Kien Lo, "The Cause and Effect of Circulation," Pao Hs1u, March, 1953, p. 101. 
why is it that the present oirculation is lower than it was before? The chlef reason rests with the language. Although the government has exerted every offort to encourage the Talwanese to learn Chinese, successful results are in ovidence only in the younger generations, students and urban dwelfers. On the contrary, farmers, workers and merchants living in the rural areas not only cannot read but also cannot speak Chinese mandarin. Th1s situation has relentlessiy hindered the clrculation expansion of the Ch1nese newspapers in the rural areas where there are more than two million farmers. The government, however, is steadily lmproving language conditions. 10

The economic factor also has handicapped newspaper circulation expansion. The monthly subscription rate of a Chinese newspaper, standerdized at $\$ 24$ N.T. (equivalent to approximately $\$ 0.66$ U.S.) 1s too costly for most laborers. The situation is even more consplcuous in the rural areas where the prices of agricultural products are 10w and the farmers cannot afford to subscribe to newspaper. This is another reason why newspepers cannot be widely clrculated In the rural areas. To further complicate matters, lowerIng of the clrculation rate is not realistic in the face of mounting production costs and moderate advertising

10Jen-Dien Lo, "On Circulation of Ta1wan Press," Pao Hs1u, August,1952, p. 101. 
revenue. 11

The Chinese newspapers, existing in such adverse conditions as discussed in the preceding paragraphs, are not discouraged in their efforts for clrculation expansion. In fact, the keen compotition among the Chinese newspapers has phystcally improved the quall ty of Chinese newspapers. As one paper strives to rget hlgher clrculation than another, 1t tries to 1mprove 1 ts typographical appearance, onrlch 1ts contents, report elaborately and accurately, and also reflect public opinion falthfully. Furthermore, all the newspapers heve been trying to improve their printing facilities so that their papers may look distinctive and ploasing to the eye. The keon competition has also resulted in a number of promotion methods. One of the methods hos been to present papers to prospective subscribers without oharge for a period ranging from three days to ten or even fifteen days. 12 But the most frequentif used method in obtalning new subscriptions is dependent on the sollciting efforts of the newsboys.

The position of the circulation manager on a Chinese nerspaper has not been given the proper attention 1t deserves. Normally, his operation is only a section

\section{Ib1d.}

12 Ib1d. 
under the business division of the management department. Jen-Dien Lo, in an article entitled "On Circulation of Ta1wan Press," published in the August, 1952, 1ssue of the Pao Hsiu, had this to say about the c1rculation manager's pos1t1on:

The economy of a newspaper depends on circulation. Th1s 1s not only true on Talwan, but also elsewhere in the world. Thus, the posetion of a circulation manager should be re-evaluated because the prosperity of a newspaper rel1es on him.... In his froquent contact $w 1$ th readers, the clrculation manager is the one that understands the needs and wants of readers, and knows what changes in typography and contents should be made so that clrculation may be increased. In the race of keen competition with other newspapers, he 18 usuelly well informed of the circulation tatus of other newspapers and is aware of proper ways to deal with the competition. H1s ouggestions will virtually hit the nail right on 1 ts head. The orgenization in a Chinese nerspaper is usualiy top-heavy and the circulation offlce is not rully developed.13

The future of better newspaper c1rculation on

Taiwan is hinged on self-sufficlency of the newspapers, greater production and rationing of newsprint, popularity of the language and the still lower price of newsprint as well as newspaper so that the masses may be able to purchase the newspapers. But the most important measure to expand c1rculation, according to Jen-Dien Lo, is to slant every newspaper to a spec1f1c group of readers 14 so that the newspapers may all prosper instead of struggling with one another for a larger share of the reading publ1c.

$$
\begin{aligned}
& 13 \text { Ib1d., p. } 103 . \\
& 14 \text { Ib1d. }
\end{aligned}
$$




\section{CHAPTER $X$}

TRANSLATION OF FOREIGN NEWS IN CHINESE PRESS

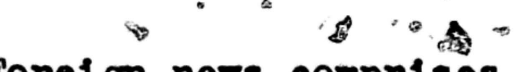

(3)

Forelgn news comprises an important part of the

contents of Chinese newspaperis. Normally, one-sixth of the space in most Chinese newspeperis is allotted to forelgn nows. But forelgn news, mostly arriving in English, has to be translated Into Chinese before it can become part of the contents of a Chinese newspaper.

Nearly all the major dall1es on Talwan have translators on the staff. The job of the translators $18 \mathrm{pr}$ marily to translate news recelved from forelgn news services or agencies, as well as articles in forelen newspapers or magazines. Elghty per cent of the International news in Chinese newspapers 18 provided by forelgn news services. I The rest comes from the facilities of the local news agenc1es or the newspaper's own forelgh correspondents The Importance of the job of translation has steadily become greater in proportion to the fast development of world ovents.

The range of forelon news recelved by Chinese newspapers may include anything--politics, military affalrs, economics, soclal events, culture, sclence and many others.

lYu1-Lang Lin, "On Translation," Pao Hs1u, Taipe1, October, 1953, p. 54 . 
Not only can translators not master all these flelds, but oven an expert specializing in one fleld may not know overything in his particular fleld of interest. Neverthelest, the translator has to translate things that are entirely outside his particular field of knowledge. In addition, he is expected to know almost everything, because he cannot expect his readers to understand his translation if he himself does not know 1t. However, even if a translator has a wide background of knowledge, it is still not onough, for the development of the world events 18 everchanging and never-ceasing. A translator must keop track of them in order that he may effectively inform h1s readors when the news comes in.

A. Principles of Translation

There are two methods in translation used in Ch1nese newspaper offices: literal translation and comprehens1ve translation.

In literal translation, every word in the original has to be fully treated, so that the meaning can be reproduced in the fullest form. The other method requires only the presentation of the meaning without following the original word by word or sentence by sentence. The method used in translating forelgn news is between the two mentioned; however the former is preferred because a trans- 
lator must be faithrul to the original weiter. ${ }^{2}$ The falthfulness 1s, more or less, a moral obligation and is regarded as one of the most important creeds that every translator should observe.

Literal translation, however, is often criticized as being unreadable or not like pure Chinese, since the translation is influenced by the gratimatilal atructure of the original language. ${ }^{3}$ Translation done by the other method, however, tends to 1080 the orlginal flavor.

The type of language used in newspaper writing, whether 1 t 18 in English or Chinese, is characterized by its simplicity, clearness and vernacularism. The language used in translation should likewlse possess these characterlstics, which $\times 111$ enable the readers to find the translation easy to read and understandable.

Timeliness 18 an important factor in the work of translation. A translator should be a fast worker so that his transiation may reach the readers while it is st1ll timely. Usually, a translator is facing before him a b1g p1le of news copy. 4 He cannot afford to delay, for news keops pouring in continualiy.

2Yul-Lang Lin, "On Newspaper Translation," A Collection of Essars on Journalism, 1955, p. 140.

3Ib1d.

4Ib1d. 
A trañlator working on a Chinese newspaper is also responsible for culling and verifying forelgn news. This is the reason why a translator is called forelgn news editor on some of the newspapers.5 But culling news is no easy job, and there should be standards in news selection. Thus, a translator must bear in mind the editorial policy of the paper with which he 18 working. The important thing, of course, is his proflciency in distinguishIng the most important from the more important, the newsiest from the newsier. There is no code that guldes these judgments except experience.

To summarize, the principles of translation are: 6

(1) Be faithrul to the original writer. Translate only what the original writor says, nothing more and nothing 10 s.

(2) As the translation 1s for others to read, the translation must be readable. Possible misunderstandings must be avo1ded.

(3) Be accurate. If there is any doubt about the accuracy of a transiation, it 1s better to iron it out before it reaches the readers.

(4) Try to think the way the original writer thinks. Only when the transiator thinks and feels the way

5Lin, "On Translation," Pao Hs1u, October, 1953, p. 55 .

6yul-Lang Lin, "On Newspaper Translation," A Collection of Essars on Journalism 1955 p. Ili" - 
he does, will he be able to fully express his idea effectively.

(5) Be prompt. Translatore must be fast workers to make up time lost through transmitting news in one language for use in a paper of another language. (6) Make sound judgment in culling and verifying forelgn news.

B. Difficulties in Translation

A translator who works for a paper must master the type of English used in newspaper writing in addition to his competency in Chinese news writing. Thus he must be able to use the proper Chinese words to express the thought of the original writer.

Mistakes are often found in translations. A translation may deviate from the original in meaning because the words chosen are not proper or not forceful enough. Even an experienced translator makes mistakes. The reason for this is that the original writer and the translators may not be "In tune" in their thinking. It is therefore natural that they think differently toward the same plece of writing. Factors that lead to mistakes in translation are usually due to the following:

(1) Mistakes from the barrier of thinking--A man's thinking is more or less influenced by his habitual mode 
of thinking and $a l s 0$ by his cultural background. It is natural that a world of difference exists between thinking based on the Eastern as opposed to Western cultures. Needless to say, a b1g difference inevitably exists in the thinking of a military man and a philosopher, or between a sclentist and a lawyer. A translator wiso attempts to translate a speech by a politician must, first of all, forget about his own habltual way of thinking and try to approach the thinking of the politician. In other words, he has to think the way a politiclan thinks. By so dolng, he can reach a better and closer approximation of the meaning of the original writer. Thus, his trensiation should appear more natural and closer to the original, Instead of having the look of being pushed or forced. But no matter how closely one thinks the way another thinks, the barrier of the two sets of thinking remains. It 1s, therefore, no wonder that an artiole, when given to ten translators, wil be translated into ten different versions. It is dangerous to translate something with which one is not familiar. The chances are that he may twist, or even contradict the original meaning. In translation work, a little knowledge is a dangerous thing.

(2) Mistakes due to the language difference--Every language has 1ts own peculiar background and spirit although there may be places where they have common attrib- 
utes. But they are st1ll different languages. To be able to understand the face meaning of individual words is far from being sufficient, for meaning changes as the situation in which a word is used varies. Each word hea its history and origin. To be able to master the English language, one must study the history, culture, religion, philosophy and legends of the English-speaking people. Engllsh words and phrases in common usage have many different origins. For instance, the phrase "Achilles hoel" is a figure of speech and refers to a Greek logend. The phrase "Milky Way" may also serve as an Interesting example. If a translator did not know what it really meant, he would certainly think it was a road split with milk when actually it represents a natural phenomenon in the sky. To translate these phrases correctly, one has to know the background Information. Surface meaning can be decelving.

(3) The difficulty in finding the proper wording equivalent to the orlginal--Being able to understand the words of one language does not mean that one can express them fully in another. The pecullarities of one language may be such that another language cannot do it justice in translation.

(4) The translator's viewpoint influences his translation--The viewpolnt of the translator oftentimes is shown in his translation. For instance, if he is a member 
of the Ant1-Saloon League, naturally he tends to put his ow thoughts, however slightly, 1nto his translation of an article about how people got drunk on Now Year's Eve at Time's Square. Of course, he has no rlght to change the description in the original, but he may infect a rather weak tone into the translation, although the translation may appear correct.

(5) English and Chinese are languages of two different orlgins. The former is alphabetical while the latter consists of characters composed of strokes and symbol1c s1gns. Ideographlcally, there 18 no similarity between the two. To translate English into French or Spanish perhaps is easier than translating it into Chinesi" because these European languages are similar so far as linguistic elements are concerned. Moreover, the difference between Ch1nese and English (or other European languages) In grammat1cal rules, in sentence structure, in order of words and in syntax further makes translation a demanding job. 


\section{CONCLUSION}

The modern Chinese press on Talwan emerged after World War II when the 1sland was returned to the Republ1c of China. During the short span of fourteen jears, the press on Talwan has made remarkable galns both in quality and quantity. At the time the Chinese government took over the 1sland in 1945, there was only one newspaper on the whole 1sland. However, three years later there were seventeen dallies beling published. Although half of them declined, net ones have arisen. Today, there are thirtytwo reglstered newspapers on Ta1wan and Penghu, an offshore 1sland, (Including two English-language da1l1es), 266 perlodicals, and 27 news agenc1es. In the city of Taipel there are twelve morning and three evening newspapers and several large news agencies, according to stat1st1es in the China Handbook, 1956-57 edition. of the 32 registered newspapers, the four greatest in terms of circulation and scale of facilities are the Central Daily News, Taiwan Hsin Sheng Pao, China Daily News and the United Daily News. Except for the United Da1ly Nows, which is a privately omed newspaper, the other three are elther Kuomintang omed or connected w th the party. In the case of the Hsin Sheng Pao, which was incorporated In 1953, the provincial government has been the largest stockholder. Viewling this situation, one naturally might 
belleve that both the Kuomintang and the government dominate the Chinese press. However, these party or government nowspapers have great froodom in ovaluating and criticizing the government and party. Nor do they reflect a rigldity of control or thought patterns. As a matter of fact, they are sometimes criticized for a lack of uniformity or consistency. Dr. Carlton Culmser wrote in 1956 of these newspapers:

Among the publishers and executives of some of these are Kuomintang party members. But it is unwise to assume that the party has in all ways a monolithic character, On the beoad alm of reuniting China it is safo to say that virtually all are agreed, but on certain other 1 ssues and means and methods there is considerable disagreement. The newspapers show a diversity of viewpoint on varlous subjects, some with Kuomintang stalwarts in high places do not always sing amall on government policies.l

The same author wote in Quill, a magazine for journal1sts, in June, 1957:

But Chinese on Formosa take actions and attitudes toward KMT [Kuomintang] which no one in Russia, for example, could take toward the Communist party. Several of the privately omed nowspapers, even some published by party members in good standing, sometimes analyze the party and KMT men in government with considerable frankness.2

The privately owned press on Taiwan is quite 1mpor-

lCarlton Culmsee, "How Free Is the Press in Free China?" Journal1sm Quarterly, Fall, 1956, p. 500.

2Carlton Culmser, "Formosan Prass Is St1ll Under Kuomintang Thumb But Is Winning Freedom," Quill, June, 1957. p. 15. 
tant. The most significant of these are United Da11y News and Kung Lun Peo and the English-language papers, China Post and China News. These newspapers are quite outspoken on many subjects and frequently criticlze the government. There are no laws curtalling press freedom and no censorship except safeguards of certain military information. 3 The Constitution of the Kopublic of China, promulgated on January 1, 1947, guarantees freedom of the press. However, as the Republic of China is still at war with the Communist Peiping regime, all printed matter 18 checked after publication. All the newspapers are anti-Communist and support the nation's struggle against Communism and their editorial policy is attuned to that effect voluntar1ly. As a matter of fact, national interests are always considered over and above anything else. The Chinese government feols the prectice is justifled because any Information salutary to the Communists or tending to disturb the peace must be checked in order to preserve national security. As a rule, all newspapers, along with other publications or printed matter, are registered before publication with competent government authorities, namely the Ministry of Interior and the Information Department of the Taiwan Provincial Government. At the present time,

\section{Ib1d.}


newspapermen on Talwan are greatly concerned about the proposed press 1aw, which they feel would tend to jeopard120 freedom of the press. But th1s law may not pass the Leg1slat1ve Yuan, the Chinese law-making body.

Because of the shortage of newsprint, the government st1pulates that all newspapers on Ta1wan, e1ther under offlcial or private ownershlp, limit thelr consumption of newsprint to six pages per single copy, except on occasions 11ke the National Hollday wen additional pages may be allowed. Th1s restriction became erfective in 1950 when forelon exchange was difficult to obtain. Prior to 1950, however, newsprint had been imported from Canada, Australla and other countries. The government 18 said to have taken steps to encourage the production capab1lity of newsprint mills, but the increase in circulation has been more rapid than that of production capability. Thus, the expansion of page numbers remains as a future possibility. Space restrictions naturally has hindered the development of newspapers, but 1 t has also helped to 1mprove the newspapers. As a matter of fact, all the papers have tried desperately to 1mprove thelr quality and typographical appearance within the same amount of space so as to win more c1rculation. Qualitative Improvement has brought prosperity to some newspapers, but it is the readers who have benef1tted w1 th better papers to read. 
Although the circulation of each individual newspaper varies from time to time, the total combined circulation of the newspapers is approximately 336,000 . As the present population of Teiwan approximates ten mililons, the total circulation suggests that overy thirty-fourth Chinese reads a newspaper. However, mention must be made of the fact that the average Chinese family usually consists of four adults and three or more chlldren who read each copy of a newspaper. Besides there are numerous coples posted at public places and both private and public organizations provide newspapers for their employees to read. Even so, the present circulation leaves much room for expansion. Advertising, wich constitutes the dominant part of the income of American newspapers, has jet to be developed in the case of Chinese newspapers. According to an estimate made in the Pao Hs1u, advertising revenue of the leading Chinese newspapers like the Central Daily News, Hsin Sheng Pao, China Da1lr Ners and the United Da11r News constitutes 45 to 55 percent of the total 1ncome. But on smaller nerspapers, the situation is not quite so good. As greater attention and efforts have been paid in recent years to the importance of advertising, this revenue has gradually constituted an important part of the income of many Chinese newspapers. Most of the advertising revenue comes from movie houses, pharmacies, commercial concerns 
and government at all levelo whlch frequently places bulletins and official announcements in the newspapers. The Centrel Dally Ners, because of 1 ts long history and prestige, enjoys the most advertising patronage, particularly in classiried and matrimonial advertisements,

All type for Chinese newepapers is hand-set. Because every Chinese word is a character which comes in a square and consists of different strokes, I1notype machines for typesetting Chinese newspapers have not yet been devised. Typesetters are probably the hardest-working people on Chinese newspapers because of the complicated nature of the job.

Apart from language, the most evident difference between a Chinese newspaper and a Western one 1108 in the way 1t is read. The Chinese newspapers are read from right to left and from top to bottom. Thus, the front page of a Chinese newspaper is the back page of a Western one. Another distingulshing feature is that the nameplate, usually witten by a prominent person with excellent penmanshlp, always appears at the upper $r 1$ ght hand corner of the front page.

Democracy requires a close relationship between the people and the government and moregrer a knowledge of what is going on both inside and outside the country. On Talwan, this knowledge is mostly channelled by newspapers. Today, the literacy rate on Ta1wan is among the highest 
In Asia, and Chinese newspapers have contributed greatly to the improved 11teracy. As China 18 adopting a democratic way of life, the understanding of national as weil as International affairs by the average person is fundamental if domocracy is to prevall. Such understanding continues to be spread largely through newspapers. It is a truism that an enlightenod publ1c 1s the best security of a nation. Today, in the face of Communist aggression and threats, such an enlightenment is noeded by the Chinese people, and the Chinese newspapers are responsible for answering that need.

Although the Chinese press has been making tremendous Improvements, long years of war and the recent Communist aggression have hindered the pace of 1 ts progress In comparison wh fournalism of other countries, particularly the United States, there remaine for the Tairan pressis the possibility for great advances in publishing techniques. Typography, news coverage, advertising, c1rculation, photo-engraving, organization and management, newsprint, freedom of press--these are among the many areas in which the Chinese press must continue to improve.

Today, the trend in the Chinese press is to follow American patterns. This is true since a great number of the key men In Chinese journallsm are American-educated, and a majority of them are graduates of the School of Journalism of the University of Missourl. Among Chinese 
journal1sts, the Missourl Schoos of Journallsm is held in the highest esteem. 


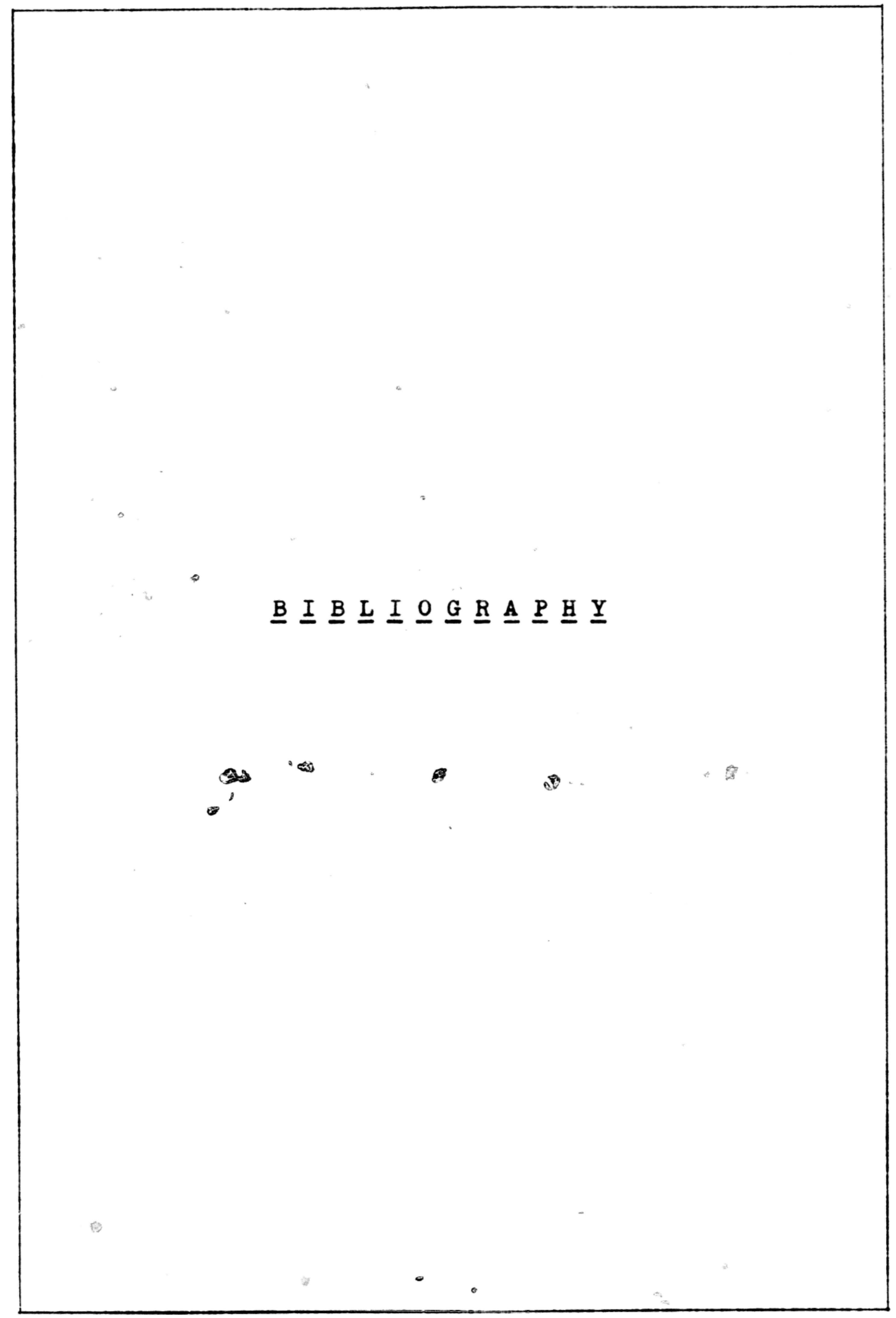




\section{A. BOOKS}

The China Handbook Editorial Board, China Handbook, 195556. Talpe1: China Publishing Company, 1955. $816 \mathrm{pp}$.

Tho China Handbook Editorial Board, China Handbook, 195651. Talpe1: China Publishing Company, 1956. 851 pp.

Chung Hwa Year Book. Ta1pe1: China News Pres8, 1957. $376 \mathrm{pp}$

Directory of Taimin. Talpe1: The China News and Publishing Serv1ce, Ltd., 1958. 208 pp.

Lin, Yul-Lang, "On Newspaper Translation," A Collection of Essars on Journal1sm, Ta1pe1: Chung Hwa Cultural

Publishing Committee, 1955. pp. 139-147.

Shieh, Jan-Tze, "Tairan Hsin Shong Pao in the Past Ten Years," Ton Years on Ta1wan. Talpel: Ta1wan Hsin Sheng Pao, 1955. pp. 280-283.

Tong, Hollington $K$ and others, A Collection of Essars on Journalism. Talpe1: Chung Hwa Cultural Publishing Committee, 1955. $237 \mathrm{pp}$.

Wu, Hs1-Tre, "Taiwan Press in the Past Ten Years," Ten Yearg on Taiwan. Ta1pe1: Tairan Hsin Sheng Pao, 1955. pp. $273-275$.

\section{B. PERIODICALS}

Chang, Oa-Feng, "The Crisis of Free China's Newspaper Advert1sing," Pao Hs1u, 4:104-05, Ta1fe1, March, 1953.

Chen, Chu-Hsin, "Circulation and Advertising--Which Is More Important?" Peo Hs1u, 10:86-88, Ta1pe1, December, 1956.

Chen, Oa, "Ta1pe1 Newspaper Advertising," Pao Hs1u, 96-103, Ta1pe1, December, 1957.

Culmser, Carlton, "How Free Is the Press In Free China?" Journal1sm Quarterly, 493-501, Fall, 1956. 
"Formosan Press Is Still Under Kuomintang Thumb But Is Winning Freedom," Quil1, 15-18, June, 1957. Kiang, The-Cheng, "On Translation," Pao Hs1u, 1:67, Ta1pe1, 1951.

Lo, Jen-Dien, "The Cause and Effect of Circulation," Pao Ho1u, 4:101-03, Ta1pe1, March, 1953.

"On the Circulation of Taiwan Press," Pao Hsiu, 3:101-03, Ta1pe1, August, 1952.

Lu, Kwan-Chuen, "Newsmen in Korean War," PaO Hs1u, 1:107111, Talpe1, 1951.

Pe1, Chien-Chu, "The Trend of Newspaper Advertising," Pao Hs1u, 5:65-69, Ta1pe1, October, 1953.

"Taiwan Commentary," East and West, 1:14-17, Ta1pe1, December, $1956^{\circ}$

Ting, We1-Tung, "The Development of the Pan-Asia Nerspaper Alliance," Pac Hs1u, 1:147, Ta1pe1, 1951.

Yao, Peng, "On Comprehensive Reporting," Pao Hs1u, 2:59-67, Ta1pe1, January, 1952.

\section{NEWSPAPERS}

孥, $\rightarrow$ in

Chang, L1-Ken, "Central Da1ly News in the Past Seven Years," Contral Dally Nows T28 th Anniversary Special Edition), March $12,1957$.

Chao, Hs1ao-S1, "Po-Sheng Chen and the Central Da1ly News," Central Daily Ners (28 th Anniversary Special Edition), March 12, 1957 .

Ch1ne Da11y News, (Southern Ed1tion), October 10, 1957. China Post, September 8, 1952; Apr11 12, 13, 14, 1958. Central Da11r News, March 12, September 1, 1957.

"Construction of the Hain Sheng Pao in the Past Nine Years," Hsin Sheng Pao NInth Anniversary Special Edition), October 25, 1954 . 
Hs1eh, Tung-Min, "Hsin Sheng Pao in the Past Nine Years," Hain Sheng Peo (NInth AnnIversary Special Edition), March 12, 1957 .

Huang, T1en-Peng, "Wartimo Press in Chungking," Central Daily News $\{28$ th Anniversary Spec1al Edition), March 12, 1957.

Yeh, M1n-Shin, "Taiwan Press Since 1954," Central Da1ly News (28th Anniversary Special Edition), March 12, 1957.

\section{PAMPHLETS}

A Brier Introduction to Tah Hwa Evening News (mimeographed).

Ta1pe1: Tah Hwa Evening News, Spring, 1958.

"Business Correspondence of the Central News Agency"

Ta1pei: Central News Agency, 1954.

"CNA--Past, Present and Future" Taipe1s Central News Agency, 1954.

Hao, Pin-Yan, "A Business Report to the Board of Directcrs of the China Daily Ners," 1956.

Ta1wan Hsin Sheng Pao Business Report, October 25, 1954. Ta1pe1: Hsin Sheng Pao, 1954.

Ta1wan Hsin Sheng Pao Business Report, October 31, 1952. Ta1pei: Hsin Sheng Pao, 1952.

United Da1ly Ners (A Brief Introduction to the Paper). I'1poi: Un1ted Da11r News, Apr11, 1958.

\section{E. UNPUBLISHED MATERIALS}

Cheng, Stanway, letter dated December 1, 1957.

- letter dated March 8, 1958

, memorandum dated December 1, 1957. 
Hoo, Pin-Yan, "Newspaper Management in China," (Handwitten manuscript), Naipe1, 1957.

Wang, Paul H. C., "A Historlcal Study of the Chinese Press of 3,000 Years." Unpublished Master's Thesis, The Un1versity of M1ssour1, Columbs, 1955. 
University Libraries

University of Missouri

Digitization Information for Theses and Dissertations project. Scanned from microfilm; no subsequent editing done.

Local identifier

Source information

Identifier

Format

Content type

Notes

Capture information

Date captured

Scanner manufacturer/model ScanPro 3000 /e-ImageData

Scanning software

optical resolution

Compression

Color settings

File types

Notes

Derivatives - Access copy

Editing software

Resolution

Color

File types

Notes
Long1 958

Microfilm reel\# T1958-52-T1958-58

Microfilm

Text

2019

PowerScan $3000(\mathrm{TM})$ v5.341

$600 \mathrm{dpi}$

LZW

bitonal

tiff

Scanned from microfilm; no editing done.

Photoshop

600 dpi

grayscale

pdf

Converted from tiff to pdf using Adobe Acrobat Pro DC. 